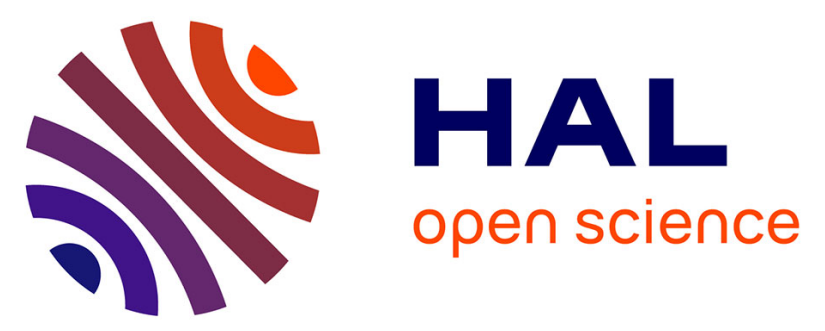

\title{
Analysis of seasonal variations in mass balance and meltwater discharge of the tropical Zongo Glacier by application of a distributed energy balance model
}

\author{
J. E. Sicart, R. Hock, Pierre Ribstein, M. Litt, E. Ramirez
}

\section{- To cite this version:}

J. E. Sicart, R. Hock, Pierre Ribstein, M. Litt, E. Ramirez. Analysis of seasonal variations in mass balance and meltwater discharge of the tropical Zongo Glacier by application of a distributed energy balance model. Journal of Geophysical Research, 2011, 116, pp.D13105. 10.1029/2010JD015105 . insu-00649274

\section{HAL Id: insu-00649274 \\ https://hal-insu.archives-ouvertes.fr/insu-00649274}

Submitted on 12 Mar 2021

HAL is a multi-disciplinary open access archive for the deposit and dissemination of scientific research documents, whether they are published or not. The documents may come from teaching and research institutions in France or abroad, or from public or private research centers.
L'archive ouverte pluridisciplinaire HAL, est destinée au dépôt et à la diffusion de documents scientifiques de niveau recherche, publiés ou non, émanant des établissements d'enseignement et de recherche français ou étrangers, des laboratoires publics ou privés. 


\title{
Analysis of seasonal variations in mass balance and meltwater discharge of the tropical Zongo Glacier by application of a distributed energy balance model
}

\author{
Jean Emmanuel Sicart, ${ }^{1}$ Regine Hock, ${ }^{2,3}$ Pierre Ribstein, ${ }^{4}$ Maxime Litt, ${ }^{5}$ \\ and Edson Ramirez ${ }^{5}$
}

Received 24 September 2010; revised 17 March 2011; accepted 25 March 2011; published 8 July 2011.

[1] A distributed energy balance model was applied to Zongo Glacier, Bolivia ( $16^{\circ} \mathrm{S}, 6000$ $4900 \mathrm{~m}$ above sea level, $2.4 \mathrm{~km}^{2}$ ), to investigate atmospheric forcing that controls seasonal variations in the mass balance and in meltwater discharge of glaciers in the outer tropics. Surface energy fluxes and melt rates were simulated for each $20 \times 20 \mathrm{~m}^{2}$ grid cell at an hourly resolution, for the hydrological year 1999-2000, using meteorological measurements in the ablation area. Model outputs were compared to measurements of meltwater discharge, snow cover extent, and albedo at two weather stations set up on the glacier. Changes in melt rate in three distinct seasons were related to snowfall and cloud radiative properties. During the dry season (May to August), the low melt rate was mainly caused by low long-wave emission of the cloudless thin atmosphere found at these high altitudes. From September to December, meltwater discharge increased to its annual maximum caused by an increase in solar radiation, which was close to its summer peak, as well as a decrease in glacier albedo. From January on, melt was reduced by snowfalls in the core wet season via the albedo effect but was maintained thanks to high long-wave emission from convective clouds. The frequent changes in snow cover throughout the long ablation season lead to large vertical mass balance gradients. Annual mass balance depends on the timing and length of the wet season, which interrupts the period of highest melt rates caused by solar radiation.

Citation: Sicart, J. E., R. Hock, P. Ribstein, M. Litt, and E. Ramirez (2011), Analysis of seasonal variations in mass balance and meltwater discharge of the tropical Zongo Glacier by application of a distributed energy balance model, J. Geophys. Res., 116, D13105, doi:10.1029/2010JD015105.

\section{Introduction}

[2] Glaciers can provide insight into climate variations in low-latitude regions, which are characterized by high water and energy exchanges between the surface and the atmosphere. Tropical glaciers are directly exposed to the influence of the El Niño-Southern Oscillation (ENSO), one of the dominant modes of interannual climate variability in lowlatitude to midlatitude regions [Jones et al., 2001]. The asynchronous fluctuations of low-latitude and midlatitude glaciers since the Last Glacial Maximum has not been thoroughly investigated [Hastenrath, 2009; Jomelli et al., 2009]. Recent observations point to a general trend of glacier recession at low latitudes throughout the 20th century [Kaser,

${ }^{1}$ LTHE UMR 5564, Université Joseph Fourier-Grenoble 1, IRD, CNRS, G-INP, Grenoble, France.

${ }^{2}$ Geophysical Institute, University of Alaska Fairbanks, Fairbanks, Alaska, USA.

${ }^{3}$ Department of Earth Sciences, Uppsala University, Uppsala, Sweden.

${ }^{4}$ UMR Sisyphe, Université Pierre et Marie Curie, Paris, France.

${ }^{5} \mathrm{IHH}$, UMSA, La Paz, Bolivia.

Copyright 2011 by the American Geophysical Union. 0148-0227/11/2010JD015105
1999; Francou et al., 2003] that has been linked to increases in air temperature [e.g., Bradley et al., 2009]. Nevertheless, owing to the lack of process-based studies, interactions between low-latitude glaciers and climate remain poorly understood.

[3] Climate controls glacier mass balance through energy and mass fluxes at the ice or snow surface. Energy flux measurements on tropical glaciers began in the 1960s but are still relatively rare [e.g., Platt, 1966; Hastenrath, 1978; Hardy et al., 1998; Mölg et al., 2009a]. In 1995, automated weather stations began to be used to monitor surface energy fluxes in the ablation area of Zongo Glacier, Bolivia, and Antizana 15 Glacier, Ecuador [Wagnon et al., 1999; Favier et al., 2004]. These studies showed that ice sublimation greatly reduces melt energy during dry periods. Wagnon et al. [2001] showed that the high melt rates measured at the Zongo Glacier weather station during the 1997-1998 El Niño year were mainly due to reduced solid precipitation and the associated low albedo. Sicart et al. [2005] showed that glaciers in the outer tropics are characterized by marked seasonality of long-wave incoming radiation because cloud emission during the wet season considerably increases longwave clear-sky emission from the thin atmosphere. They also showed that during the dry season, turbulent fluxes are increased by katabatic winds in a cloudless sky. 


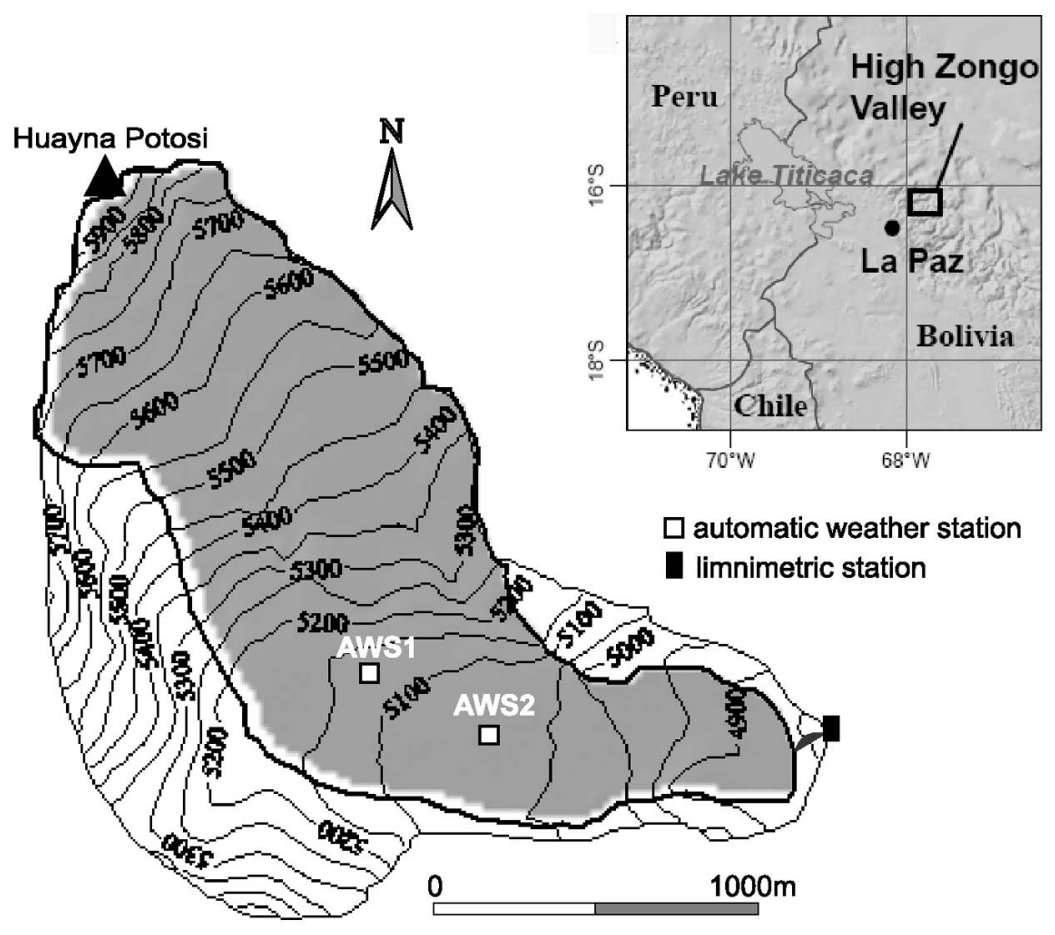

Figure 1. Map of Zongo Glacier showing the locations of the monitoring equipment.

[4] The interpretation of point-scale energy flux measurements can lead to erroneous generalizations of melt characteristics when they are extrapolated to the whole glacier. For example, albedo is highly variable near the snowline, so that the contribution of solar radiation to melt energy depends on the location of the weather station. A distributed energy balance model is thus required to investigate the link between atmospheric forcing and the total glacier mass balance and quantify the contribution of meltwater to water resources downstream. In the tropics, Mölg et al. [2009b] applied a distributed energy balance model to a slope glacier on Mount Kilimanjaro, equatorial East Africa, to investigate the climatic causes of the glacial recession that began at the end of the 19th century.

[5] This paper discusses the application of the distributed energy balance model of Hock and Holmgren [2005, hereinafter HH05] to Zongo Glacier in Bolivia. The model was developed on Storglaciären, Sweden, and has been applied to the King George Island ice cap [Braun and Hock, 2004]. HH05 calculates the surface energy fluxes for each glacier grid cell from measurements collected at a weather station in the ablation area. The model is based on equations of mass and energy conservation and the parameters have, in principle [Beven, 1989], a physical interpretation, so they can be linked to measurable physical quantities. However, natural subgrid heterogeneities often cause a mismatch of scales between measured and modeled variables [Klemes, 1983; Seibert, 1999]. For instance, the characteristic length scale of the glacier albedo is a few tens centimeters, whereas the grid size of distributed models is at best a few tens meters. Consequently, the HH05 model had to be adapted to tropical high mountains. This adaptation mainly concerned parameterization of (1) the snow albedo due to the frequent alternation of melt and snowfall during the wet season and (2) the sky long- wave radiation due to its marked seasonality. To achieve general applicability and to avoid compromising their physical interpretation, parameters were as far as possible taken from the literature or from field observations, independently of model runs. A parsimonious approach was chosen to minimize the number of parameters and to match model complexity with the availability of field observations.

[6] The objective was to examine the climatic factors that control seasonal and spatial variations in the mass balance of Zongo Glacier, specifically the sources of melt energy, the drastic reduction in the melt rate during the dry season, and the large vertical mass balance gradients. The simulations were analyzed in the framework summarized by Grayson et al. [1992, p. 2659]: "The most appropriate uses of processes-based, distributed-parameter models are to assist in the analysis of data, to test hypotheses in conjunction with field studies, to improve our understanding of processes and their interactions and to identify areas of poor understanding in our process description." First, we discuss the point-scale parameterization and spatial extrapolation of each energy flux in the specific context of tropical high mountains. Second, we analyze the grid-based energy flux simulations and resulting discharges for the hydrological year September 1999 to August 2000.

\section{Physical Setting and Model Data}

\subsection{Location and Measurements}

[7] Zongo Glacier is situated in the Huayna Potosi Massif $\left(16^{\circ} 15^{\prime} \mathrm{S}, 68^{\circ} 10^{\prime} \mathrm{W}\right.$, Cordillera Real, Bolivia) on the western margin of the Amazon basin and on the eastern margin of the Altiplano catchment. This valley type glacier is $3 \mathrm{~km}$ long, has a surface area of $2.4 \mathrm{~km}^{2}$, and ranges from 6000 to $4900 \mathrm{~m}$ above sea level (asl) (Figure 1). The equilibrium line altitude 
Table 1. List of Sensors at AWS1 and AWS2 With Their Specifications ${ }^{\mathrm{a}}$

\begin{tabular}{|c|c|c|c|}
\hline Quantity & $\begin{array}{l}\text { AWS2 }(5060 \mathrm{~m} \text { asl }) \\
\text { Sensor Type }\left(\text { Height }^{\mathrm{b}}\right)\end{array}$ & $\begin{array}{l}\text { AWS1 }(5150 \mathrm{~m} \text { asl }) \\
\text { Sensor Type }\left(\text { Height }^{\mathrm{b}}\right)\end{array}$ & $\begin{array}{l}\text { Accuracy According } \\
\text { to the Manufacturer }\end{array}$ \\
\hline Air temperature ${ }^{\mathrm{c}}\left({ }^{\circ} \mathrm{C}\right)$ & Vaisala HPM45C (1 m) & Vaisala HPM45C aspirated $(0.3$ and $1.8 \mathrm{~m})$ & $\pm 0.2^{\circ} \mathrm{C}$ \\
\hline Relative humidity ${ }^{\mathrm{c}}(\%)$ & Vaisala HPM45C $(1 \mathrm{~m})$ & Vaisala HPM45C aspirated (0.3 and $1.8 \mathrm{~m})$ & $\begin{array}{l} \pm 2 \% \text { in }(0-90 \%) \\
\quad \pm 3 \% \text { in }(90-100 \%)\end{array}$ \\
\hline Wind speed $\left(\mathrm{m} \mathrm{s}^{-1}\right)$ & Young $05103(2.5 \mathrm{~m})$ & Young $05103(0.3$ and $1.8 \mathrm{~m})$ & $\pm 0.3 \mathrm{~m} \mathrm{~s}^{-1}$ \\
\hline Wind direction (deg) & Young $05103(2.5 \mathrm{~m})$ & Young $05103(0.3$ and $1.8 \mathrm{~m})$ & $\pm 3 \mathrm{deg}$ \\
\hline $\begin{array}{l}\text { Incident short-wave } \\
\text { radiation }\left(\mathrm{W} \mathrm{m}^{-2}\right)\end{array}$ & $\begin{array}{l}\text { Kipp \& Zonen CM3 }(1 \mathrm{~m}) \\
0.3<\lambda<2.8 \mu \mathrm{m}\end{array}$ & $\operatorname{SKYE~SKS1110~}(1 \mathrm{~m}), 0.4<\lambda<1.1 \mu \mathrm{m}$ & $\begin{array}{l}\text { CM3: } \pm 10 \% \text { for daily sums } \\
\text { sp1100: } \pm 3 \%\end{array}$ \\
\hline $\begin{array}{l}\text { Reflected short-wave } \\
\text { radiation }\left(\mathrm{W} \mathrm{m}^{-2}\right)\end{array}$ & $\begin{array}{l}\text { Kipp \& Zonen CM3 }(1 \mathrm{~m}) \\
0.3<\lambda<2.8 \mu \mathrm{m}\end{array}$ & $\operatorname{SKYE~SKS1110~}(1 \mathrm{~m}), 0.4<\lambda<1.1 \mu \mathrm{m}$ & $\begin{array}{l}\text { CM3: } \pm 10 \% \text { for daily sums } \\
\text { sp1100: } \pm 3 \%\end{array}$ \\
\hline $\begin{array}{l}\text { Incoming long-wave } \\
\text { radiation }\left(\mathrm{W} \mathrm{m}^{-2}\right)\end{array}$ & $\begin{array}{l}\text { Kipp \& Zonen CG3 }(1 \mathrm{~m}) \\
\quad 5<\lambda<50 \mu \mathrm{m}\end{array}$ & - & $\pm 10 \%$ for daily sums \\
\hline $\begin{array}{l}\text { Outgoing long-wave } \\
\text { radiation }\left(\mathrm{W} \mathrm{m}^{-2}\right)\end{array}$ & $\begin{array}{l}\text { Kipp \& Zonen CG3 (1 m), } \\
\quad 5<\lambda<50 \mu \mathrm{m}\end{array}$ & - & $\pm 10 \%$ for daily sums \\
\hline $\begin{array}{l}\text { Net all-wave } \\
\quad \text { radiation }\left(\mathrm{W} \mathrm{m}^{-2}\right)\end{array}$ & $\begin{array}{l}\text { Calculated from the four } \\
\text { preceding quantities }\end{array}$ & REBS Q7 $(1 \mathrm{~m}), 0.25<\lambda<60 \mu \mathrm{m}$ & $\pm 10 \%$ for daily sums \\
\hline $\begin{array}{c}\text { Surface elevation } \\
\text { changes }(\mathrm{mm})\end{array}$ & - & $\begin{array}{l}\text { Ultrasonic depth gauge } \\
\text { Campbell UGD01 }(1.5 \mathrm{~m})\end{array}$ & $\pm 1 \mathrm{~cm}$ \\
\hline
\end{tabular}

${ }^{a}$ Data (half hourly means) were recorded at $20 \mathrm{~s}$ time intervals except for wind direction and accumulation/ablation, which are instantaneous values recorded every $30 \mathrm{~min}$. Sensors whose data were used as inputs in the model are in bold. For locations of AWS1 and AWS2, see Figure 1.

${ }^{\mathrm{b}}$ AWS2 is a tripod resting freely on the surface of the glacier. The mast of AWS1 was drilled into the ice. Height changes were derived from ultrasonic depth gauge measurements and field visits every 15-20 days.

${ }^{\mathrm{c}}$ The Vaisala hygro-thermometers at AWS2 were shielded from solar radiation and artificially ventilated. Artificial aspiration could not be maintained at AWS1 because of insufficient power supply.

is roughly $5200 \mathrm{~m}$ asl for a zero annual mass balance [Sicart et al., 2007]. Zongo Glacier is part of the $3.7 \mathrm{~km}^{2}$ drainage basin of the limnimetric station located at $4830 \mathrm{~m}$ asl. The station comprises a water level recorder and a triangular weir to measure the proglacial stream discharge at $15 \mathrm{~min}$ time steps.

[8] Two Campbell Automatic Weather Stations located on the glacier (AWS1 at $5150 \mathrm{~m}$ asl and AWS2 at $5060 \mathrm{~m}$ asl) collected data from September 1999 to August 2000 (Figure 1 and Table 1). Sensor characteristics and measurement uncertainties at AWS2 are discussed by Sicart et al. [2005]. Qualitative observations of the glacier surface and meteorological conditions were made every 15-20 days during field visits throughout the year. Precipitation, temperature and humidity measurements beyond the thermal influence of the glacier were recorded by a weather station located at $4750 \mathrm{~m}$ asl, approximately $1 \mathrm{~km}$ from the glacier front.

[9] The AWS2 measurements of air temperature and humidity, wind speed and global radiation (short-wave irradiance) were used as model inputs. No data were recorded from 3 to 10 February 2000. During the remaining study period, errors in temperature, humidity and radiation measurements were detected for about $4 \%$ of the hourly data. The anemometer was out of order from 25 February to 24 April 2000. These data gaps were filled using correlations with measurements made at AWS1. Owing to errors stemming from the fact the pyranometer was covered with snow during snowfall, the short-wave irradiance data were adjusted to yield a maximum fresh snow albedo of 0.9 .

[10] Solid precipitation was derived from ultrasonic depth gauge measurements at AWS1 following the methods described by Sicart et al. [2002]. Owing to the alternation of melt and snowfall during the wet season, variations in the height of the ultrasonic gauge were calculated at a $3 \mathrm{~h}$ time step. The changes in height were multiplied by a fresh snow density of $250 \mathrm{~kg} \mathrm{~m}^{-3}$, derived by comparing ultrasonic and rain gauge measurements, to be converted into units of water equivalent. The snowfall rate was then considered to be constant for each hour within the recorded $3 \mathrm{~h}$ time step. As the rain gauge network in the basin did not reveal any significant altitude gradient in precipitation [Sicart et al., 2007], the snowfall events recorded by the ultrasonic gauge were considered to be uniformly distributed throughout the basin. No rainfall was observed on the glacier but some hail may have fallen near the glacier snout during the wet season. Rain and hail were distinguished from snow on the basis of an air temperature threshold of $+1.5^{\circ} \mathrm{C}$ [Lejeune et al., 2007].

\subsection{Climate}

[11] The Huayna Potosi Massif is located in the outer tropics, characterized by marked seasonality of precipitation and cloud cover, with a single wet season in austral summer and a pronounced dry season in winter [Troll, 1941]. The dry season (May-August) is produced by the northward displacement of the midtropospheric and upper tropospheric westerlies that prevent moisture influx from the east. During the wet season (September-April), precipitation is associated with intense solar heating of the Altiplano surface leading to destabilization of the boundary layer and to deep convection and moist air advection from the eastern interior of the continent linked with the South American monsoon [e.g., Vera et al., 2006; Garreaud et al., 2009]. In winter, nonstormy precipitation occasionally occurs when the tropical atmosphere is destabilized by extratropical cold air incursions.

[12] Figure 2 shows atmospheric forcing on Zongo Glacier during the 1999-2000 hydrological year counting from 1 September, the end of the dry season. Precipitation events became increasingly frequent from September to December. The core of the wet season lasted from January to March and was characterized by frequent snowfalls, on average two days out of three. The snowfalls ended in April and remained rare until the end of the dry season, in August. The annual cycle of air humidity reflected the alternation of the wet and dry seasons. In contrast, thermal seasonality was low: less than $8^{\circ} \mathrm{C}$ 


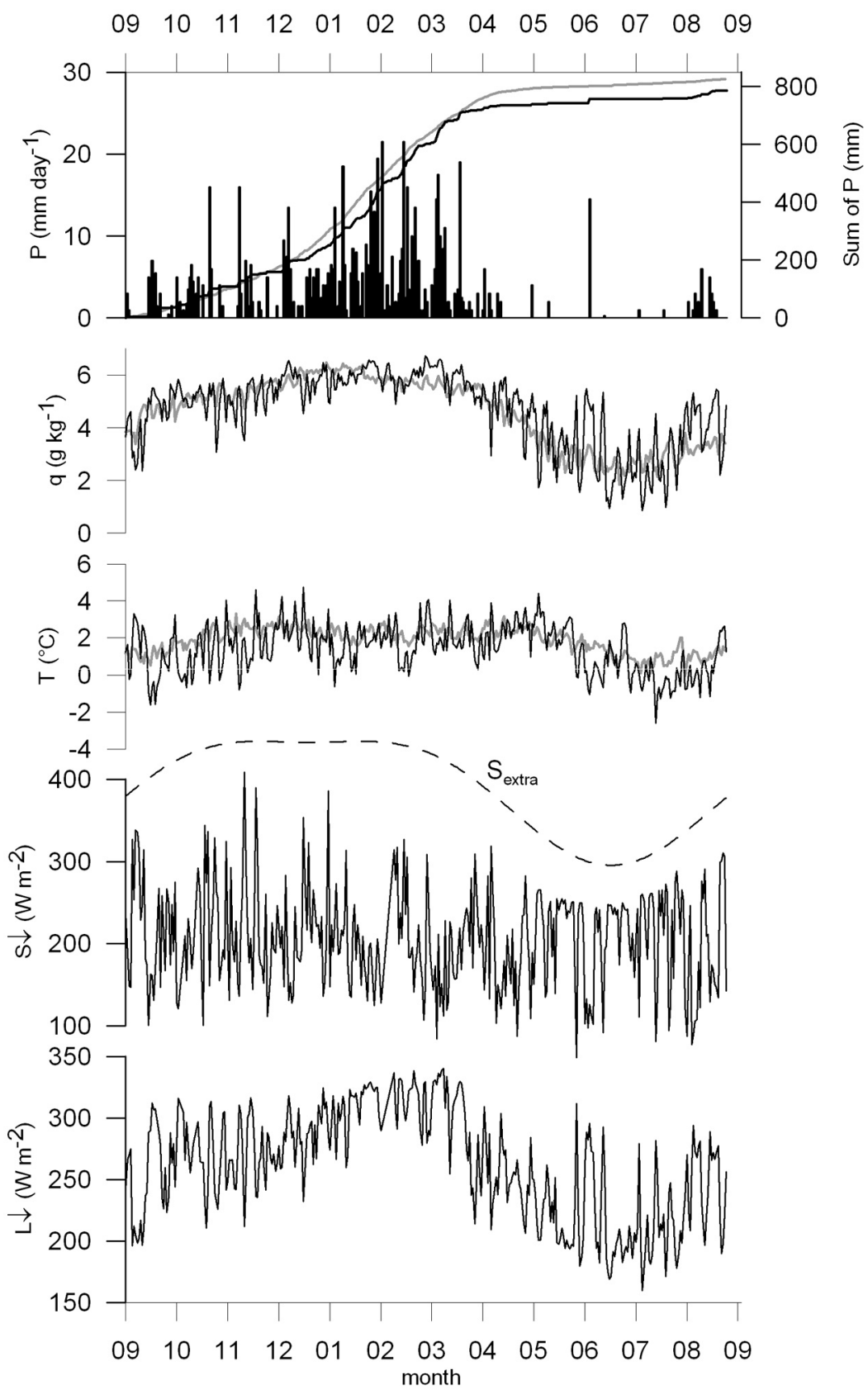

Figure 2. Precipitation ( $P$, daily and cumulative values), air specific humidity $(q)$, and temperature $(T)$ recorded outside the glacier at $4750 \mathrm{~m}$ asl and incoming short-wave $(S \downarrow)$ and long-wave $(L \downarrow)$ radiation fluxes recorded at AWS2 (5060 m asl) from September 1999 to August 2000 (solid black lines). The gray lines show the averages of cumulated $P, q$, and $T$ for the period 1995-2009. The dashed line shows theoretical extraterrestrial solar irradiance $\left(S_{\text {extra }}\right)$.

using daily averages. Changes in precipitation, humidity and temperature at $4750 \mathrm{~m}$ asl were similar to the mean annual cycles for the period 1995-2009, suggesting no anomalous climatic conditions during the study year. However, there was a slight precipitation deficit, the wet season ended early, and the dry season was slightly colder than average.

[13] Tropical glaciers receive high clear-sky solar radiation because of the high Sun elevation (low latitude) and high atmospheric transmissivity (high altitude) (Figure 2). Clouds caused marked interdaily variations in solar irradiance at the glacier surface. In contrast, seasonal variations in solar irradiance were not remarkable because of the low latitude and frequent presence of clouds in summer (wet season) when extraterrestrial solar radiation is highest. In the central Andes, cloud emissions influence the variations in long-wave radiation much more than clear-sky emissivity or the temperature of the emitting atmosphere [Sicart et al., 2010]. Figure 2 shows that clouds caused high long-wave irradiance during the wet season. During the dry season, long-wave irradiance was very low owing to prevailing clear-sky conditions, and the rare clouds caused abrupt increases in long-wave irradiance. 


\subsection{Simulation Periods and Validation Data}

[14] The simulations were conducted for two periods for which continuous records of all input and discharge data were available: 24 November 1999 to 2 February 2000 in the wet season (period 1, 71 days) and 12 February to 31 July 2000, which includes the end of the wet season and most of the dry season (period 2, 170 days). Figure 3 shows the time series of precipitation, proglacial discharge, snow free area as a percentage of glacier surface, albedo, and relative height of the surface. The annual 1999/2000 mass balance was slightly positive: $+120 \mathrm{~mm}$ w.e. Proglacial discharge was highest in the wet season and lowest in the dry season. At the outlet of the basin, around $85 \%$ of the annual precipitation and $70 \%$ of the annual discharge occur between October and March [Sicart et al., 2007].

[15] Variations in snow cover extent determined from photos and visual observations during field visits were generally in agreement with those inferred from albedo measurements (Figures 3b-3d). The snow cover was thin at the start of the first simulation period, which facilitated modeling initialization. From September to December, snowfalls alternated with periods of strong melting. The glacier surface at AWS1 remained snow covered, whereas new snow rapidly melted at AWS2, causing the albedo to drop to ice values. Proglacial discharge was greatest from November to December, when the snowline was highest. From January to April, snowfalls were frequent enough to maintain a snow cover over most of the glacier surface and the albedo remained high at both weather stations. The discharge remained quite high, at $>0.20 \mathrm{~m}^{3} \mathrm{~s}^{-1}$. Subsequently the albedo at AWS1 gradually decreased to values around 0.6 , indicating a firn surface, only interrupted by a few snowfalls. Discharge dropped after a heavy snowfall in early June and remained low until the end of the hydrological year.

[16] Model outputs were compared to observations of the snow cover extent and measurements of discharge and albedo at the two weather stations. Whereas on midlatitude glaciers, the snowline progressively rises in elevation during the summer, tropical glaciers are frequently covered by a thin cover of snow during the ablation season (Figure 3). Ablation stakes were not used as validation data because the measurements were not available at a short enough time step, and the snow density was not routinely measured.

\section{Surface Energy Balance and Runoff Model}

[17] Melt energy was derived from the energy balance equation for every hour and for each $20 \times 20 \mathrm{~m}^{2}$ grid cell:

$$
\begin{gathered}
R+H+L E+P_{h}=\Delta Q_{M}+\Delta Q_{S}, \\
\Delta Q_{S}=\int_{0}^{z^{*}} \frac{d(\rho c T)}{d t} d z,
\end{gathered}
$$

where $R$ is net radiation, $H$ and $L E$ are the turbulent fluxes of sensible and latent heat, respectively, and $P_{h}$ is the heat advected by precipitation. The term $\Delta Q_{S}$ represents the change in heat content in a control volume of ice or snow and $\Delta Q_{M}$ is the energy used for melting (positive) or freezing (negative). $\rho$ and $c$ are density and specific heat, respectively, and $T$ is the ice temperature. $z^{*}$ is the depth at which the energy fluxes become zero. The fluxes are expressed in
$\mathrm{W} \mathrm{m} \mathrm{m}^{-2}$ and are considered as positive if they supply energy to the control volume. $P_{h}$ is very low on Zongo Glacier and is disregarded hereafter [Sicart et al., 2005].

[18] When the rates of change over a period of $1 \mathrm{~h}$ are small, steady state conditions can be assumed:

$$
R+H+L E=\Delta Q_{M}
$$

The energy available for melt, $\Delta Q_{M}\left(\mathrm{~W} \mathrm{~m}^{-2}\right)$, derived from equation (2), is converted into meltwater equivalent ( $\mathrm{mm}$ $\mathrm{h}^{-1}$ ), which provides the input for runoff modeling. Meltwater is routed through the glacier by three parallel linear reservoirs representing the storage properties of firn, snow, and ice, using storage constants of 350,30 , and $16 \mathrm{~h}$, respectively, taken from HH05. Firn is here defined as snow that was not ablated during the previous year. Water flows through the Zongo Glacier are poorly known and major uncertainties remain in this simple drainage model. The firn area is defined as the glacier area above $5150 \mathrm{~m}$ asl. Off the glacier, snow rarely lasts for more than a few days. Nonglaciered areas (30\% of the basin representing around $10 \%$ of the total discharge in the wet season) are mainly composed of lateral moraines and outcrops of granodiorite. Its runoff is estimated with a constant runoff coefficient $c_{e}=0.8$ [Ribstein et al., 1995]. Sicart et al. [2007] showed that the uncertainty of this coefficient has a limited effect on the estimation of glacier meltwater discharge. The calculations of each energy flux are detailed in HH05 and are summarized below, with emphasis on the adaptations required for tropical high mountains.

\subsection{Radiation}

[19] Net radiation can be written as

$$
R=S \downarrow-S \uparrow+L \downarrow-L \uparrow=S \downarrow(1-\alpha)+L \downarrow \varepsilon-\varepsilon \sigma T_{s}^{4},
$$

where $S \downarrow$ is global radiation, $S \uparrow$ is reflected short-wave radiation $(S=S \downarrow-S \uparrow$ is net short-wave radiation), and $L \downarrow$ and $L \uparrow$ are long-wave irradiance and emittance, respectively $(L=$ $L \downarrow-L \uparrow$ is net long-wave radiation). $\alpha$ is surface albedo, $\varepsilon$ is the long-wave emissivity of ice, $\sigma=5.6710^{-8} \mathrm{~W} \mathrm{~m}^{-2} \mathrm{~K}^{-4}$ is the Stefan-Boltzmann constant, and $T_{s}$ is surface temperature $(\mathrm{K})$.

\subsubsection{Global Radiation}

[20] Measured global radiation was separated into direct $(I)$ and diffuse $(D)$ components, which were then extrapolated individually to each grid cell taking terrain effects into account. The separation is based on the atmospheric transmissivity of short-wave radiation $\left(\tau_{\text {atm }}\right)$ calculated as the ratio of measured global radiation $S \downarrow$ to theoretical extraterrestrial solar radiation $S_{\text {extra }}$ :

$$
\tau_{\text {atm }}=S \downarrow / S_{\text {extra }} .
$$

With increasing cloudiness, $\tau_{\text {atm }}$ decreases while the diffuse portion $D / S \downarrow$ increases.

[21] Hourly measurements with a shadow band at AWS1 from 25 to 30 July 2000 showed that, owing to the thin atmosphere at high altitude, clear-sky diffuse irradiance represented only $\sim 6 \%$ of global radiation. This is in agree- 

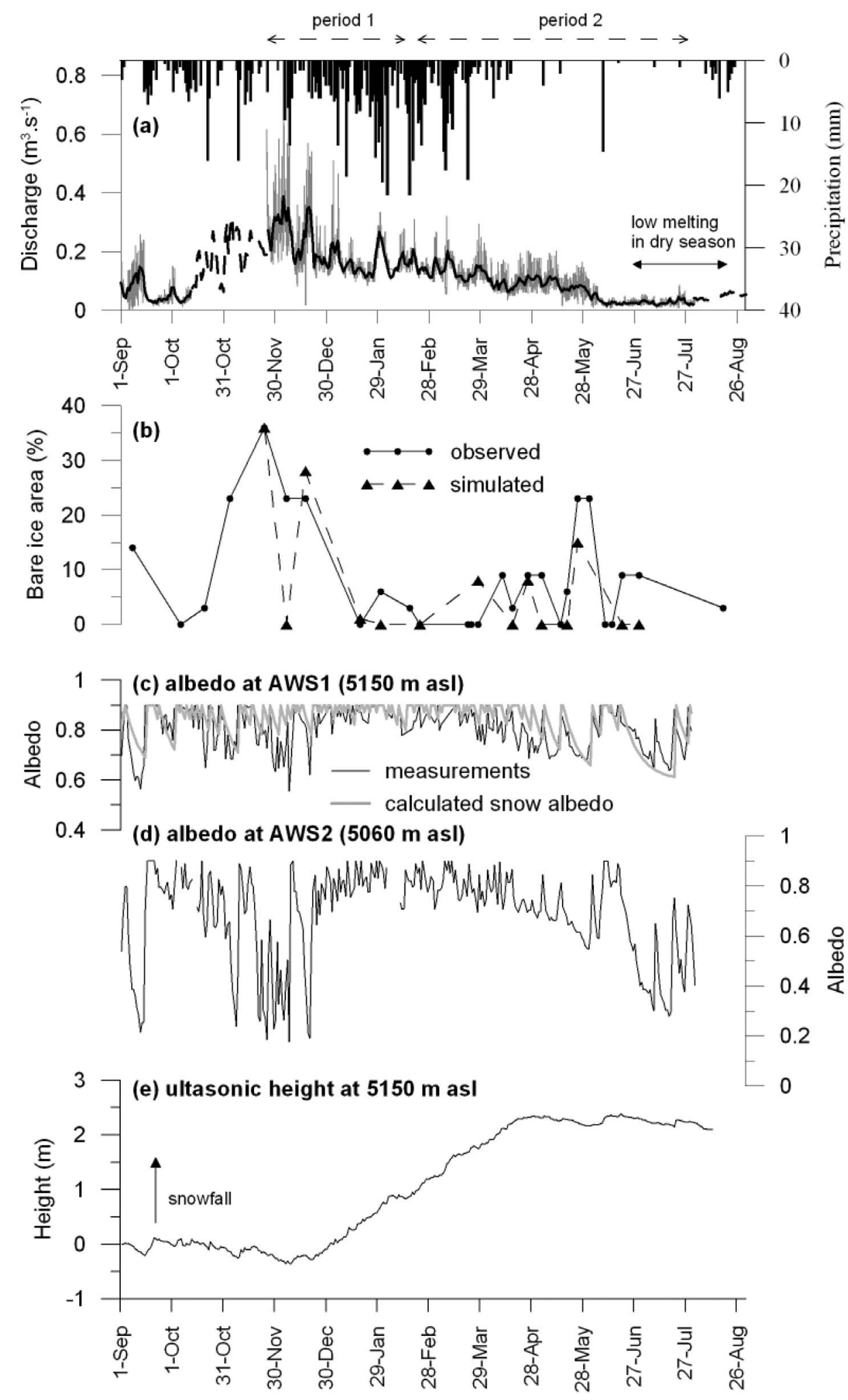

Figure 3. (a) Discharge: hourly (in gray) and daily (in black) values. Measurement gaps in October and November were filled using correlations with meteorological data (dashed line) [Berthier et al., 2001]. Precipitation recorded at $4750 \mathrm{~m}$ asl is shown on the $y$ axis on the right. (b) Bare ice area as a percent of glacier surface. (c, d) Albedo measured daily at AWS1 and AWS2, respectively (the gray line shows snow albedo calculated from equation (7)). (e) Daily ultrasonic depth at AWS1: a decrease in height is due to ablation or snowpacking, and an increase in height is due to snowfall. Figures 3a-3e are for September 1999 to August 2000. 
ment with other measurements made on high-altitude tropical glaciers [e.g., Hastenrath, 1978; Mölg et al., 2009a] while on Storglaciären, northern Sweden, a percentage of $\sim 15 \%$ was found [Hock and Holmgren, 2005]. The measurements also indicated that the empirical relationship of HH05 between $D / S \downarrow$ and $\tau_{\text {atm }}$ can be applied to Zongo Glacier:

$$
D / S \downarrow=0.06 \text { if } \tau_{\text {atm }} \geq 0.8,
$$

$$
\begin{aligned}
& D / S \downarrow=0.929+1.134 \tau_{\text {atm }}-5.111 \tau_{\text {atm }}^{2}+3.106 \tau_{\text {atm }}^{3} \\
& \quad \text { if } 0.15<\tau_{\text {atm }}<0.8,
\end{aligned}
$$

$$
D / S \downarrow=1.0 \text { if } \tau_{\text {atm }} \leq 0.15
$$

Equation (5a) was corrected for low clear-sky diffuse radiation at high elevations. Global radiation is entirely diffuse when measured $S \downarrow$ is $<15 \%$ of $S_{\text {extra }}$ (equation (5c)). For each hour between sunrise and sunset, equation (5), together with measured global radiation, was used to obtain diffuse radiation at AWS2, which was then subtracted from global radiation to yield the direct solar radiation at this site. Topographic shading was calculated for each hour and for each grid cell from the path of the Sun and the effective horizon. If the weather station was shaded by the surrounding topography, any measured global radiation was assumed to be diffuse. Clear-sky direct solar irradiance was calculated for each grid cell from the theoretical potential direct solar irradiance considering grid slope and aspect, reduced by clearsky attenuation, which is about $13 \%$ on Zongo Glacier. The attenuation of direct solar irradiance by clouds was derived from the AWS2 measurements and assumed to be uniform at the scale of the glacier.

[22] Total diffuse irradiance $\left(D_{t}\right)$ was calculated for each grid cell by distinguishing sky diffuse radiation, which was uniform at the scale of the glacier, from radiation reflected by surrounding slopes:

$$
D_{t}=D V_{f}+S \downarrow \alpha_{s}\left(1-V_{f}\right),
$$

where $V_{f}$ is the sky view factor (the fraction of the celestial hemisphere visible from the surface, defined normal to the slope) and $\alpha_{s}$ is calculated as the mean albedo over all grid cells in the drainage basin.

\subsubsection{Albedo}

[23] HH05 calculates the snow albedo in a recursive way: the change in albedo from the previous time step is a function of temperature and precipitation. In the dry season, snow metamorphism on Zongo Glacier is slow and diurnal changes in albedo are almost not detectable by the pyranometers. In fact, hourly measurements of clear-sky albedo are disturbed by the surface slope even at small slope angles [Sicart et al., 2001]. In the wet season, snow metamorphism is faster and should be detected by the pyranometers. However, frequent snowfalls may cover the sensors and disturb the measurements, and the spectral effects of cloud on the albedo may be significant at a short time step [Warren, 1982]. For these reasons, we considered that the $\mathrm{HH} 05$ albedo calculations could not be tested on Zongo Glacier owing to the lack of reliable observations at an hourly time scale. Instead, we applied the U.S. Army Corps of Engineers' [1956] wide- spread aging curve approach, which represents the rapid decrease in snow albedo $\left(\alpha_{\text {snow }}\right)$ after snowfall by an exponential function of the number of days since snowfall $(n)$ :

$$
\alpha_{\text {snow }}=\alpha_{\text {firn }}+\left(\alpha_{\text {fresh }}-\alpha_{\text {firn }}\right) e^{\left(-n / n^{*}\right)} .
$$

The snow albedo decreases from the fresh snow value $\left(\alpha_{\text {fresh }}=0.9\right)$ toward an asymptote representing the firn albedo $\left(\alpha_{\text {firn }}=0.6\right)$, with $n^{*}$ being the time scale parameter (days). Figure $3 \mathrm{c}$ suggests that the time scale $n^{*}=10$ days, which is similar to values applied in tropical and in midlatitude glaciers [e.g., Kuhn et al., 1999; Mölg et al., 2009b], is appropriate to simulate the albedo transition from fresh snow to firn when the snowpack is thick.

[24] To account for solar radiation penetration through the snow to the underlying ice, the albedo of thin snow layers was calculated as a polynomial function of the snow water equivalent $(s)$, similarly to Oerlemans and Knap [1998]:

$$
\alpha=\alpha_{\text {snow }}+\left(\alpha_{\text {ice }}-\alpha_{\text {snow }}\right)\left(1+s / s^{*}\right)^{-3},
$$

where $\alpha_{\text {snow }}$ is derived from equation (7), $\alpha_{\text {ice }}$ is the ice albedo and $s^{*}$ is a scale parameter (mm w.e.). Different depths of solar radiation penetration through snow have been documented, from a few centimeters to a few decimeters [e.g., Bergen, 1971; Grenfell and Maykut, 1977]. Most of this variation may be due to differences in snow density and in the characteristics and concentration of dust in the snow [Warren, 1984]. Here, we consider $s^{*}=6 \mathrm{~mm}$ w.e., so that the underlying ice starts to affect the surface snow albedo at about $3 \mathrm{~s}^{*}=18 \mathrm{~mm}$ w.e.

[25] Snowfall rates are generally low on Zongo Glacier, less than a few millimeters w.e. per hour [Sicart et al., 2002]. During light snowfalls, the albedo of the underlying ice tends to reduce the snow albedo. Following HH05, the increase in albedo $(\Delta \alpha)$ during snowfall was assumed to be proportional to the snowfall intensity $\left(P_{s}\right.$, in $\mathrm{mm}$ w.e. $\left.\mathrm{h}^{-1}\right)$ as

$$
\Delta \alpha=c P s
$$

where $c=0.02$ (mm w.e. $)^{-1}$.

[26] The ice albedo on Zongo Glacier varied from around 0.4 to 0.2 , with no steady pattern emerging (e.g., Figure 3), owing to the concentration of dust and cryoconite holes that developed at the surface. As the concentration of dust is expected to increase toward the glacier front, the simulation of temporal and spatial variations of the ice albedo would require at least two parameters that are difficult to estimate [e.g., Mölg et al., 2009b]. Here we assumed a constant and uniform value of $\alpha_{i c e}=0.35$, corresponding to the average of the AWS2 measurements over the two hydrological years 1998-1999 and 1999-2000.

\subsubsection{Long-Wave Radiation \\ 3.1.3.1. Sky Emission}

[27] HH05 derives sky long-wave irradiance as the residual of the radiation balance at the weather station using measurements of net radiation, global and reflected solar radiation, and the computed value of outgoing long-wave radiation. However, bias errors accumulate in residual methods and net radiation measurements can be affected by large errors [Halldin and Lindroth, 1992]. Here, we use the equation that Sicart et al. [2010] derived from measurements on Zongo 
Glacier and on Antizana Glacier in Ecuador. Clear-sky emissivity was calculated according to Brutsaert [1975], and cloud emissivity was calculated as a linear function of the daily atmospheric transmissivity of short-wave radiation ( $\tau_{\text {atm }}$, equation (4)). The sky long-wave irradiance in an open environment, $L_{0} \downarrow\left(\mathrm{W} \mathrm{m}^{-2}\right)$, is then written as

$$
L_{0} \downarrow=1.15(e / T)^{1 / 7}\left(1.67-\tau_{\text {atm }} 0.83\right) \sigma T^{4},
$$

where $e$ is hourly air vapor pressure (hPa) and $T$ is hourly temperature $(\mathrm{K})$.

\subsubsection{Emission From the Surrounding Terrain}

[28] In HH05, the long-wave emission from surrounding slopes is simulated using the parameterization of Plüss and Ohmura [1997], which accounts for the emission of air between the emitting surface and the receiving surface. On Zongo Glacier, this parameterization led to an air emission of less than $10 \mathrm{~W} \mathrm{~m}^{-2}$, that is, close to the measurement uncertainty range. Thus, assuming isotropic sky and terrain radiance, the surface long-wave irradiance in rugged terrain is simply written as

$$
L \downarrow=V_{f} L_{0} \downarrow+\left(1-V_{f}\right) \varepsilon_{s} \sigma T_{s}^{4},
$$

where $V_{f}$ is the sky view factor, $\varepsilon_{s}$ is the terrain emissivity, close to unity for most natural surfaces, and $T_{s}$ is the temperature of the emitting terrain $(\mathrm{K})$, computed as

$$
T_{s}=273.2 \mathrm{~K}
$$

for emitting ice and snow surfaces (highest emission), and

$$
T_{s}=T+c_{t} S \downarrow
$$

for emitting rock faces, where $c_{t}=0.01 \mathrm{~K} \mathrm{~W}^{-1} \mathrm{~m}^{2}$. Uncertainty can be large in equation (12b), which was derived on an alpine glacier by Greuell et al. [1997]. However, Sicart et al. [2006] showed that in steep topography, total incoming longwave radiation is more sensitive to the sky view factor than to the temperature of the emitting surfaces. Except for a rock face on the west side of the glacier, which reduces the effective horizon for the plateau at $5200-5300 \mathrm{~m}$ asl (Figure 1), the sky view factor is rather high on Zongo Glacier with a mean of 0.87 and a standard deviation of 0.07 . The temperature of the rock face derived from equation $(12 b) \mathrm{did}$ not exceed $15^{\circ} \mathrm{C}$, which seems reasonable. For the $60 \%$ of the glacier area where $V_{f}>0.85$, the increase in $L_{0} \downarrow$ caused by terrain emission was slight, close to measurement uncertainty. In the remaining $40 \%$ of the glacier area with a steep slope or surrounded by steep topography, terrain emission was significant and could increase $L_{0} \downarrow$ by a few tens of $\mathrm{W} \mathrm{m}{ }^{-2}$, causing approximately $20 \%$ of spatial variability in long-wave irradiance.

\subsubsection{Glacier Emission}

[29] Ice is considered to be a full emitter $(\varepsilon=1)$, so the reflection of long-wave radiation is disregarded (equation (3)). This assumption, which affects the apparent surface temperature by a few degrees when $T_{s}$ is close to $273 \mathrm{~K}$, is acceptable considering the accuracy of long-wave radiation measurements. The surface temperature is assumed to be the melting point if the energy available for melt is positive. If melt energy turns negative, the surface temperature is lowered iteratively in
$0.25 \mathrm{~K}$ steps until the energy budget reaches zero. An iterative loop is needed because the surface temperature affects emission of long-wave radiation and turbulent heat fluxes.

\subsection{Turbulent Fluxes}

[30] The turbulent fluxes of sensible $(H)$ and latent $(L E)$ heat were calculated using the bulk aerodynamic method, including stability correction. The nondimensional stability functions for momentum, heat, and moisture are expressed in terms of Monin-Obukhov length according to Beljaars and Holtslag [1991] for the stable case and to the Businger-Dyer expressions for the infrequent unstable case. The MoninObukhov length, in which the buoyant flux is approximated by $H$, was determined by iteration at each time step at AWS2, as detailed in $\mathrm{HH} 05$. The stability functions were then assumed to be spatially invariant across the glacier.

[31] On Storglaciären, $\mathrm{HH} 05$ calibrated the roughness lengths to yield optimal agreement between the simulated and measured discharge, obtaining $z_{0}=10 \mathrm{~mm}$ for momentum and $z_{0 T}=z_{0 q}=z_{0} / 100$ for temperature and humidity, respectively. On Zongo Glacier, Wagnon et al. [1999] assumed that the three roughness lengths were equal and used them as a calibration parameter to fit the calculated sublimation derived from $L E$ to the measured sublimation with weighing lysimeters. During the year 1999-2000, no penitents appeared and the effective roughness length varied from 1 to $5 \mathrm{~mm}$ (mean, $3 \mathrm{~mm}$ ) at AWS2 [Sicart et al., 2005]. Wind and temperature profile data were collected from an eight-level $6 \mathrm{~m}$ mast at $5060 \mathrm{~m}$ asl during a period of one month in the 2007 dry season [Ben Tahar, 2008]. The results gave $\mathrm{z}_{0}$ values ranging from 1 to $10 \mathrm{~mm}$ and $z_{0 T} \approx z_{0} / 100$, in agreement with the observed rough surface. Eddy correlation measurements during the same experiment confirmed this range of values for $z_{0}$. Here, the values $z_{0}=10 \mathrm{~mm}$ and $z_{0 T}=$ $z_{0 q}=z_{0} / 100$ were applied at the AWS2 location. A $15 \%$ decrease in roughness length per $100 \mathrm{~m}$ increase in altitude was applied and the lengths for fresh snow were reduced by a factor of 10 compared to ice and snow [e.g., Smeets and van den Broeke, 2008].

[32] The weather stations were located too close to one another to enable investigation of spatial variability of temperature, humidity, or wind speed. A constant lapse rate of air temperature was set at $-0.55 \mathrm{~K}$ per $100 \mathrm{~m}$ [Berthier et al., 2001], whereas relative humidity and wind speed were assumed to be invariant in space.

\section{Results}

[33] As the spatial distribution of long-wave irradiance is more uniform than that of short-wave irradiance or of the turbulent fluxes, and as accurate simulation of the surface temperature would require more complete calculation of the subsurface heat flux, the reference simulation considers the incoming and outgoing long-wave radiation fluxes as uniform inputs derived from measurements made at AWS2 ( $T_{s}$ is derived from $L \uparrow$ ). The calculation of long-wave irradiance is tested in section 4.4. Two sensitivity tests are described in section 4.2: (1) the time scale parameter for snow albedo recession was set at $n^{*}=6$ days instead of at 10 days as in the reference run (equation (7)), and (2) the turbulent fluxes were constrained to zero. 

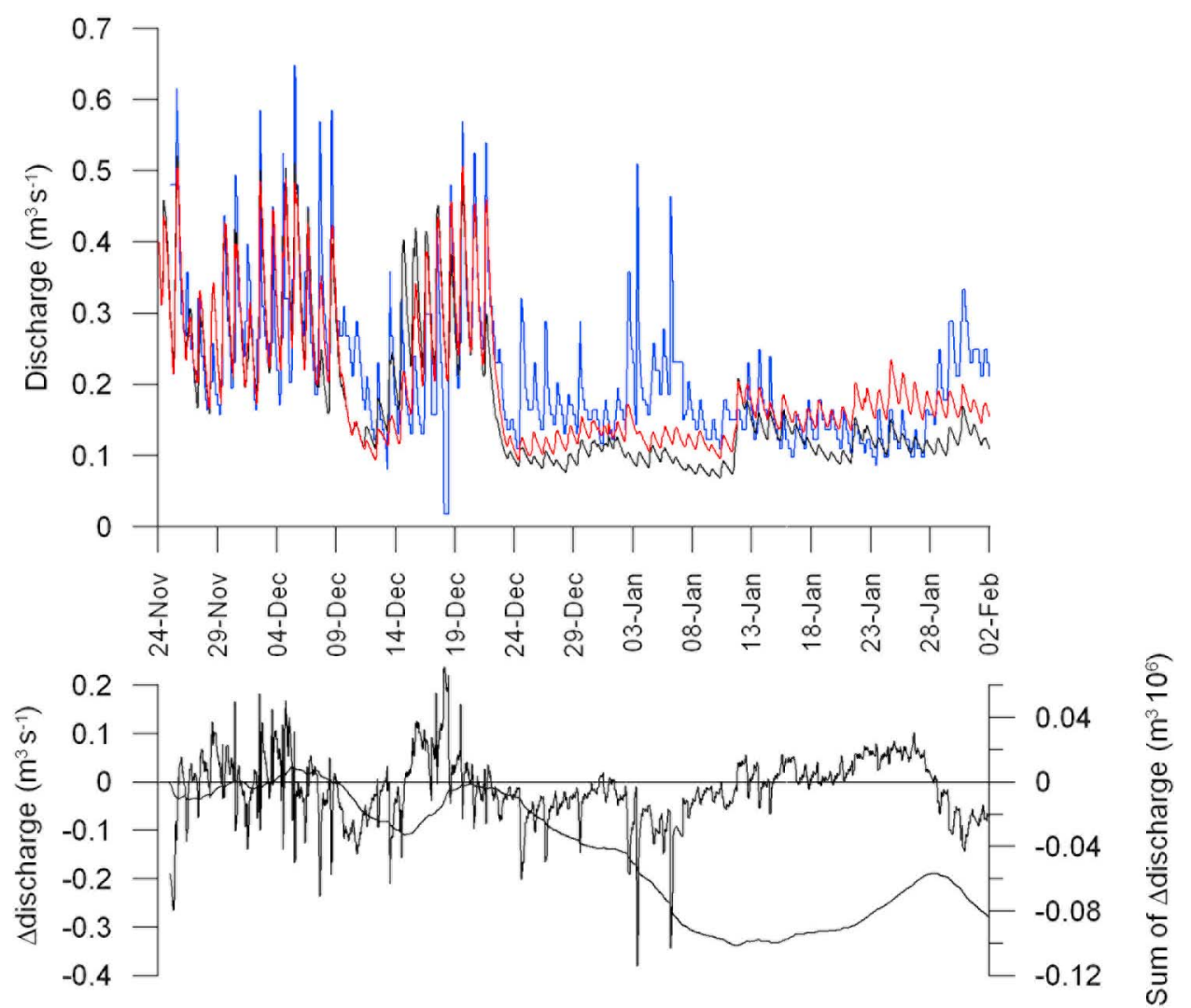

Figure 4. (top) Hourly discharge during period 1: measurements (blue line), reference simulation (red line), and simulation using calculations of the long-wave radiation fluxes (black line). (bottom) Difference between the reference simulation and the measurements (hourly and cumulative values).

\subsection{Discharge and Energy Fluxes in the Wet Season (Period 1)}

[34] During period 1, discharge was substantial, its cumulative sum was $12.610^{5} \mathrm{~m}^{3}$, corresponding to about half of the yearly total (Figure 3a). Figure 4 compares simulated and measured discharge. Differences were large at short time scales: for instance, many peaks in early January were missed by the model. Toward the end of period 1 , the simulated base flow was slightly overestimated. Overall, most of the errors canceled each other out and the total meltwater production was close to observed values (cumulated difference, $7 \%$ ). The high discharges from November to December were mostly due to ice melting, characterized by a short delay in runoff and marked diurnal cycles (Figure 5). From January on, the snowline remained low and ice melt was reduced. Melting of snow temporarily covering the ablation area progressively

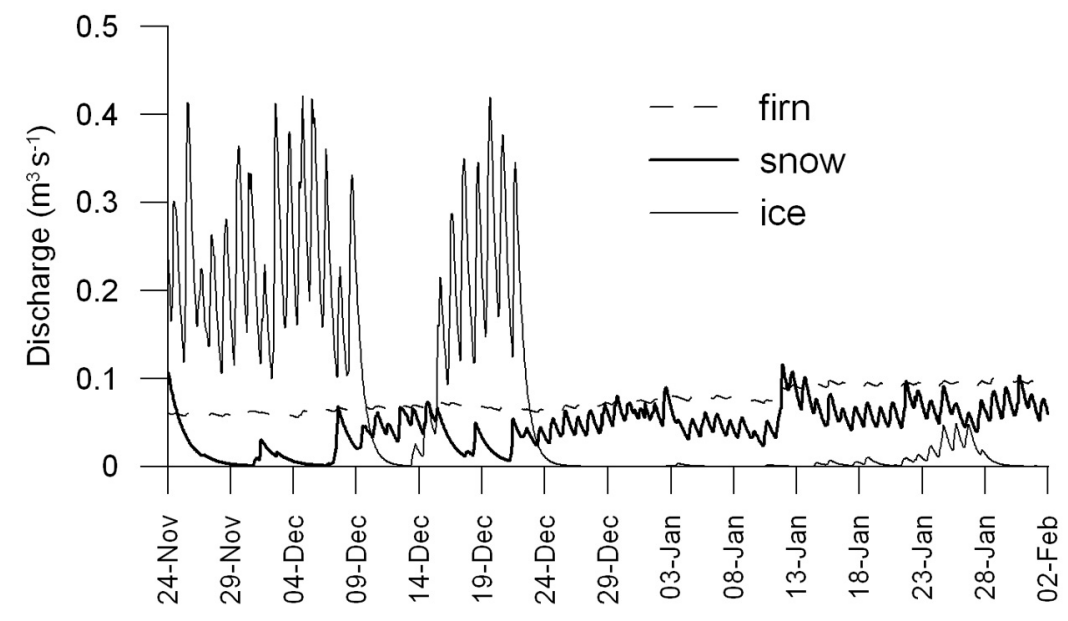

Figure 5. Contribution of firn, snow, and ice areas to meltwater discharge during period 1. 


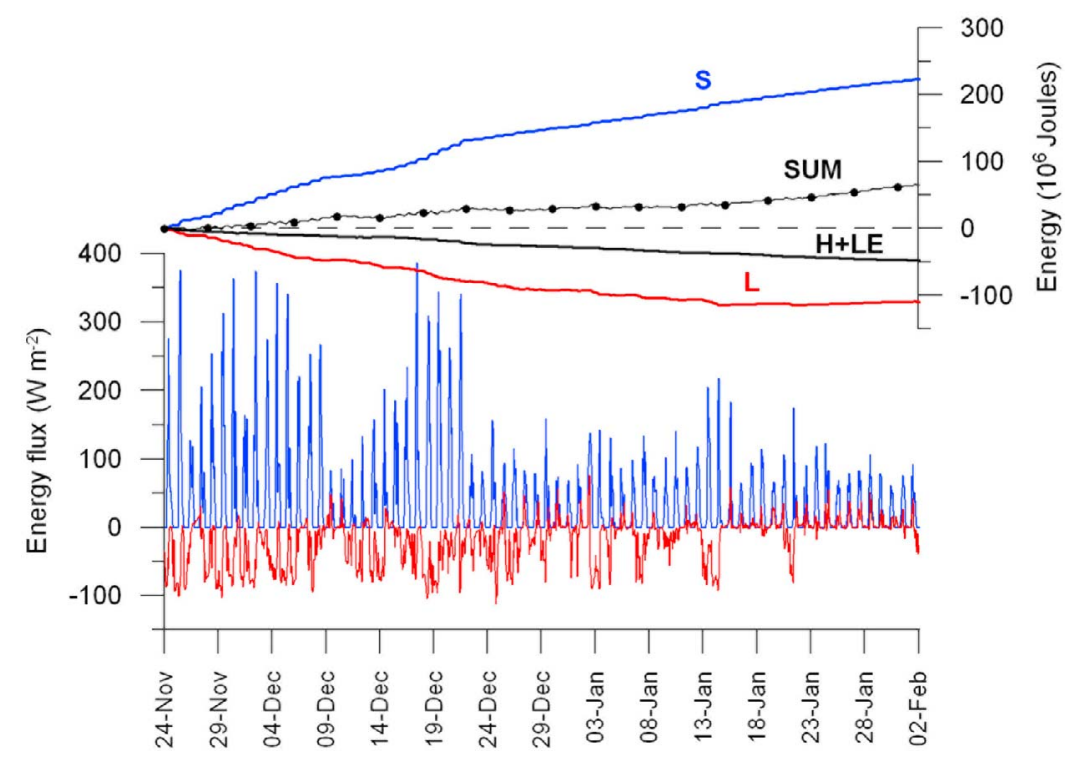

Figure 6. Mean hourly energy fluxes over the entire glacier during period 1 . The $y$ axis on the left refers to hourly fluxes (turbulent fluxes not shown), and the $y$ axis on the right shows cumulative energy amounts. Net short-wave radiation ( $\mathrm{S}$, in blue), net long-wave radiation (L, in red), and the sum of turbulent fluxes (in black). The black line with dots shows the cumulative sum of the atmospheric energy fluxes (SUM).

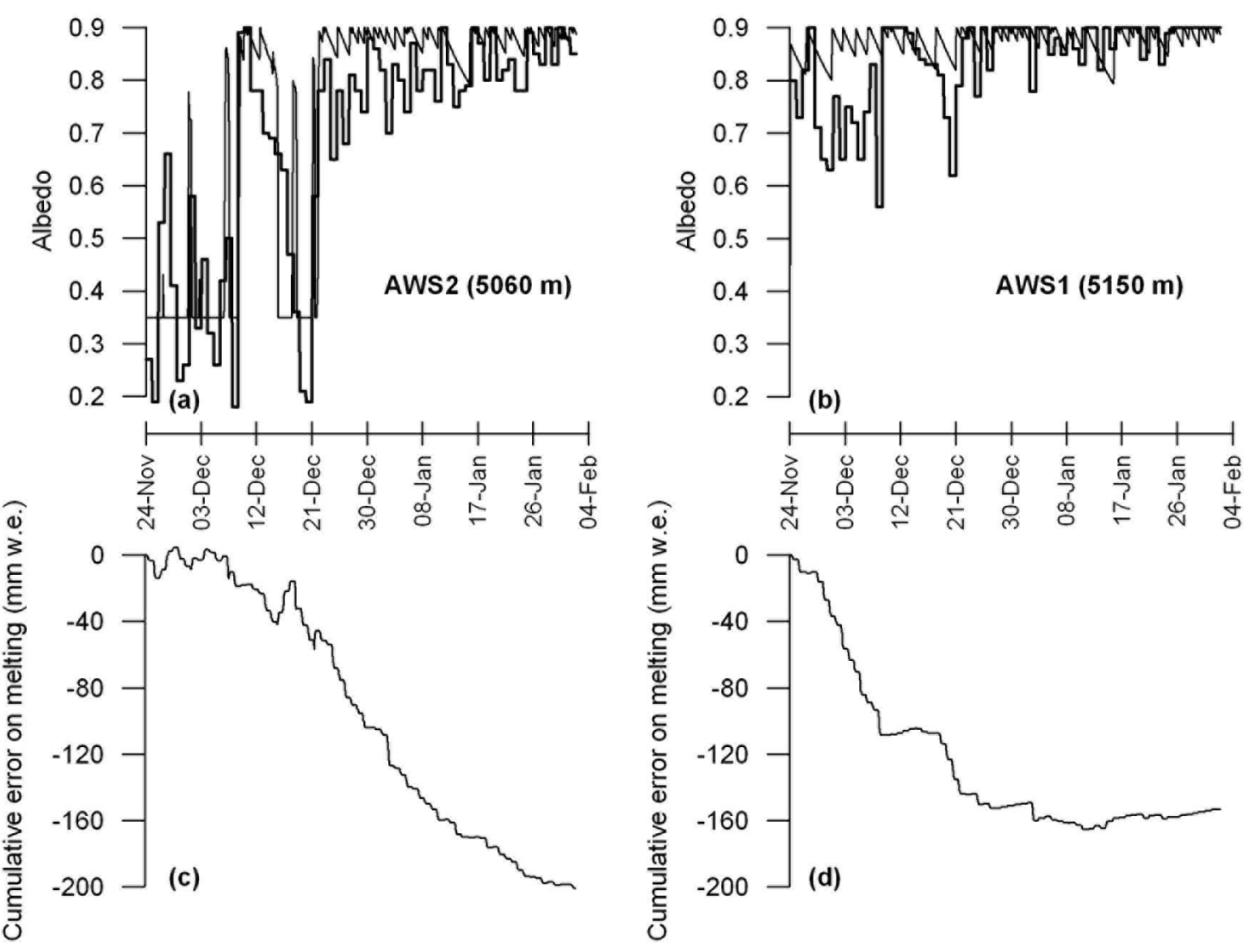

Figure 7. (a, b) Measured (thick line) and simulated (thin line) albedo during period 1 at AWS2 and AWS1, respectively. (c, d) Cumulative error in melting due to differences between measured and calculated albedo at AWS2 and AWS1, respectively ( $\Delta$ melting $<0$ if the simulated albedo is too high). 


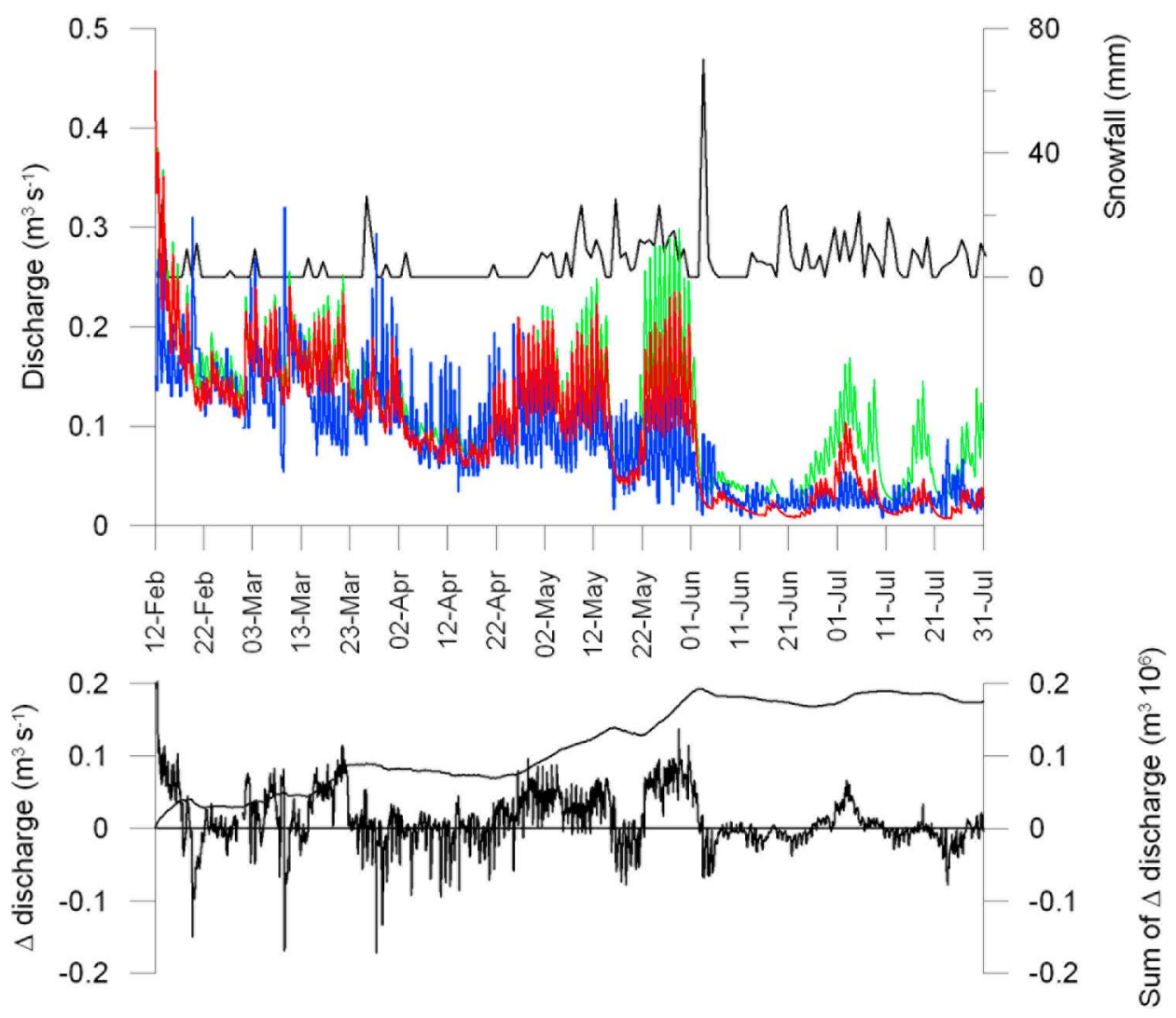

Figure 8. (top) Hourly discharge during period 2: measurements (blue line), reference simulation (red line), and simulation with $H+L E=0$ (green line). Snowfalls measured at AWS1 are on the $y$ axis on the right. (bottom) Difference between the reference simulation and the measurements (hourly and in cumulative values).

increased, and, at the end of period 1 , reached similar amounts to the meltwater outflow from the firn area, which remained fairly constant.

[35] Turbulent fluxes were low in the wet season; hourly averages during period 1 did not exceed $20 \mathrm{~W} \mathrm{~m}^{-2}$ in any glacier grid cell. The (small) energy gain in turbulent sensible heat flux mostly offset the energy loss in latent heat (sublimation). Radiation fluxes prevailed in the energy balance and the day-to-day variations in melt energy were controlled by net short-wave radiation (Figure 6). From November to December, net short-wave radiation was high, reaching hourly values of $400 \mathrm{~W} \mathrm{~m}^{-2}$ as averaged over the entire glacier, causing the highest discharges of the year (Figures 3 and 4). Net long-wave radiation was negative, offsetting about $25 \%$ of the highest gains in $S$ around midday. Snowfalls became frequent from late December on, the high albedo of fresh snow reduced $S$ and meltwater discharge. Owing to cloud emissions, net long-wave radiation was close to nil (and often slightly positive), thus contributing to (or at least not reducing) melt energy.

[36] Figure 7 compares the albedo simulations with measurements made at the two weather stations. Also shown is the cumulated error in melting due to the errors in albedo. The simulations were in rough agreement with observations; the transitions from snow to ice were quite well simulated because equation (8) accounts for the albedo of thin snow layers. At first, overestimation of the ice albedo at AWS2 caused a slight underestimation of the melt rate. When snow remained at the surface, calculations slightly overestimated albedo causing significant underestimation of cumulated melt, which reached about $200 \mathrm{~mm}$ w.e. at the end of period 1 (around 20\% of total melt). Errors in snow albedo at AWS1 also caused underestimation of the melt rate, but to a lesser extent. The discharge peaks of ice melt in early January were underestimated because albedo errors caused overestimation of the snow cover (Figures $3 b$ and 4 ).

\subsection{Changes in Melt Rate From the Wet to the Dry Season (Period 2)}

[37] The snowline was low and discharge remained moderate during period 2 (Figure 3). The sum of discharge was $1210^{5} \mathrm{~m}^{3}$, similar to the amount in period 1 , which was less than half as long. The discharge simulations were in reasonable agreement with observations; the drastic reduction in melt in the dry season was well simulated (Figure 8). However, like in period 1, the simulated base flow, which mainly came from the firn area, was often too high (especially in May) and many discharge peaks were missed by the model (e.g., in April). The simulation overestimated cumulated discharge by $14 \%$.

[38] Solar radiation at the glacier surface was not greatly reduced in the dry season compared to the summer wet season (Figure 2). Net solar radiation remained less than $250 \mathrm{~W} \mathrm{~m}^{-2}$ as a mean over the glacier owing to high albedo (the mean for 


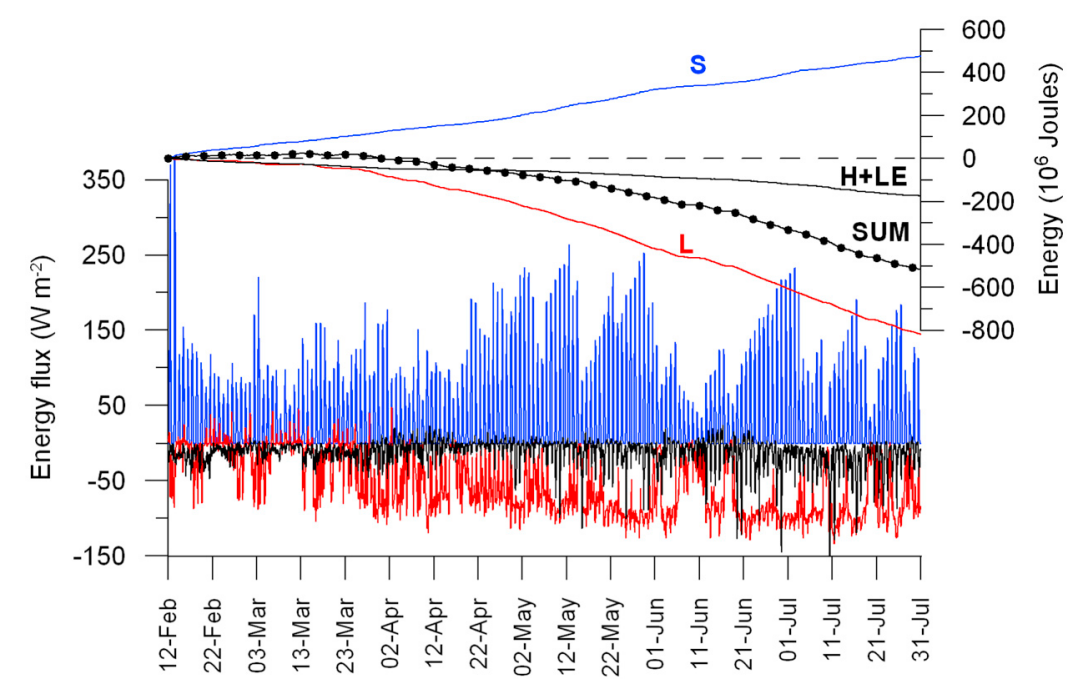

Figure 9. Mean hourly energy fluxes over the entire glacier during period 2. The $y$ axis on the left refers to hourly fluxes, and the $y$ axis on the right refers to the cumulated energy. Net short-wave radiation (blue line), net long-wave radiation (red line), and the sum of turbulent fluxes (black line). The black line with dots shows the cumulative sum of the atmospheric energy fluxes (SUM).

period 2 was 0.7 ; Figure 9). Net long-wave radiation, close to nil in the wet season, represented a large energy sink on cloudless days during the dry season (frequently less than $-100 \mathrm{~W} \mathrm{~m}^{-2}$ ). The turbulent fluxes $H+L E$ were negative, and reached $-50 \mathrm{~W} \mathrm{~m}^{-2}$. The cumulated sum of energy fluxes started to decrease in April as diurnal energy gains did not compensate for high losses during the night.

[39] During the night of 4 June, heavy snow covered the entire glacier ( $80 \mathrm{~mm}$ at AWS2), causing a drop in discharge (Figures 3 and 8). The energy available for melt remained low until the end of the dry season. However, the simulated albedo and snow cover were overestimated at both weather stations, as in period 1. At AWS2, the simulated snow cover did not disappear during period 2, whereas measured albedo decreased to ice values in July (Figure 10, $n^{*}=10$ days, reference run). In order to accelerate the decrease in the snow albedo, a simulation was run with the time scale parameter $n^{*}$ $=6$ days (equation (7)). As a result, the June snowfall melted in July, but the simulated snow cover also disappeared in May, whereas the measured albedo remained high (Figure 10). The decrease in the albedo after snowfall was too rapid when $n^{*}=6$ days, causing too much melting and very high discharges ( $+58 \%$ compared to values measured during period 2$)$. In fact, in the dry season, the model overestimated the sensitivity of the melt rate to the albedo. The simulated discharge significantly increased as the snowline rose in July, whereas measured discharge remained low; it did not increase when ice appeared at $5060 \mathrm{~m}$ asl (Figures 3 and 8).

[40] Figure 8 also shows a simulation with turbulent fluxes constrained to zero. In the wet season up to May, turbulent

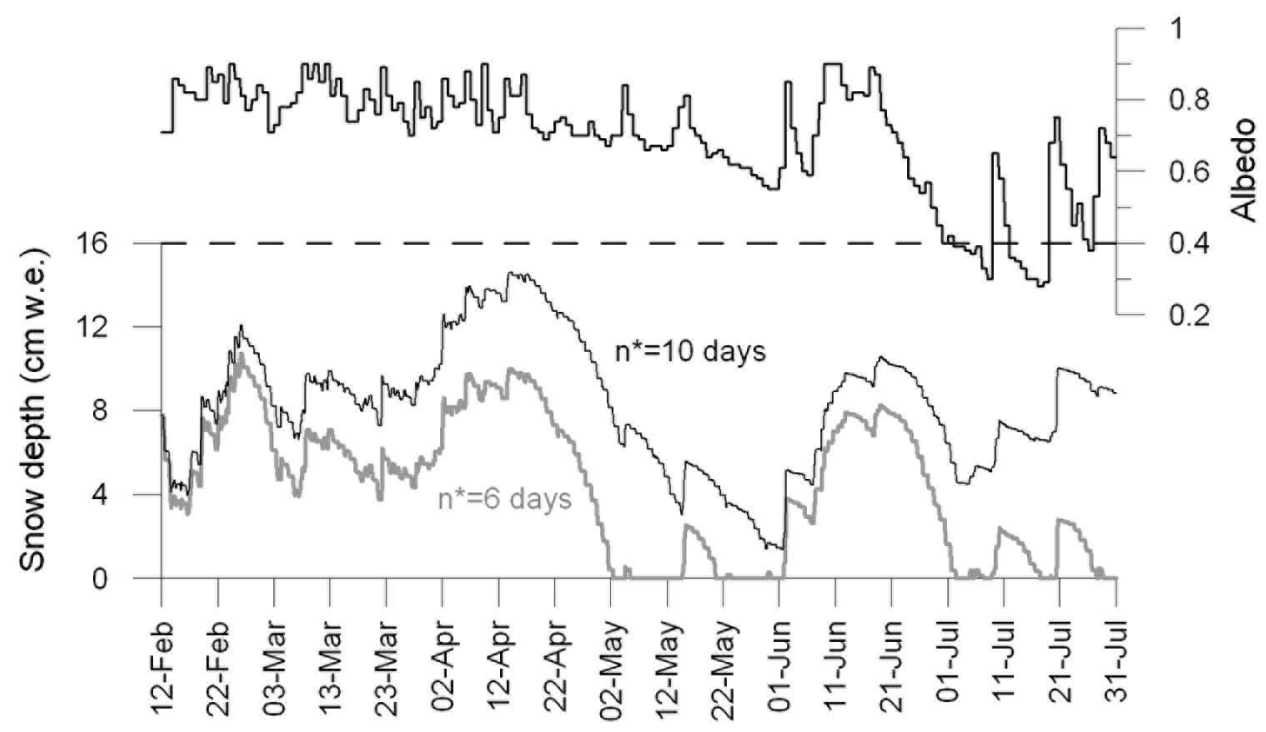

Figure 10. Albedo measurements at AWS2 and simulated snow depth with $n^{*}=10$ days (reference run) and with $n^{*}=6$ days, during period 2 . 


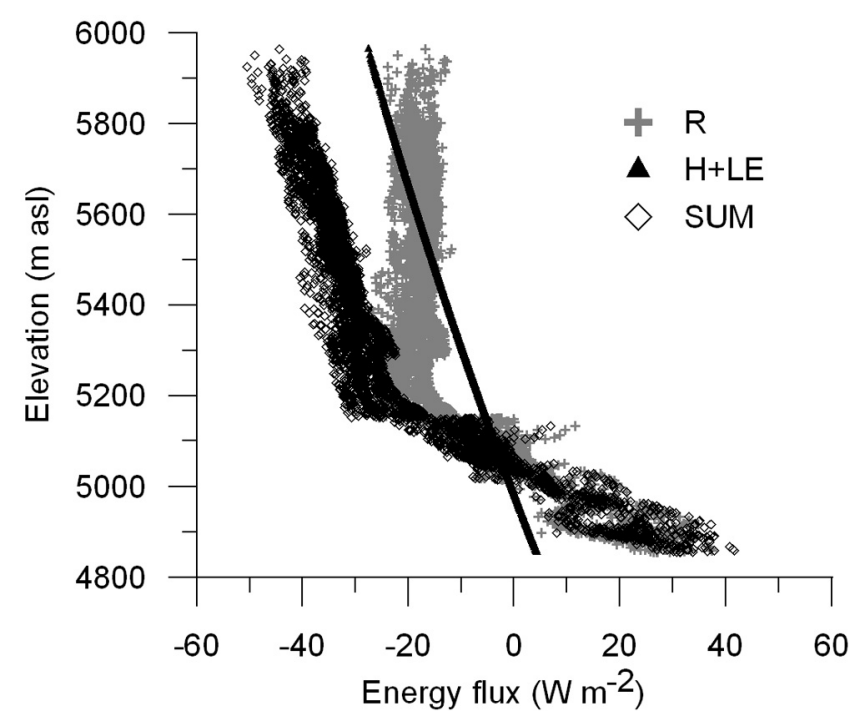

Figure 11. Hourly energy fluxes versus elevation averaged over periods 1 and 2 .

fluxes were low, with no significant effect on the melt rate. Subsequently, sublimation prevailed in the turbulent fluxes, which became an energy sink during the day and reduced the melt rate. Switching off the turbulent fluxes increased meltwater discharge, especially its firn outflow component. However, the melt rate was drastically reduced in June even when simulations were performed without turbulent fluxes.

\subsection{Variations in Energy Fluxes and Melt Rate According to Elevation}

[41] Figure 11 shows the strong dependence of the simulated energy fluxes on elevation. In the ablation area, the large gradient of the time-averaged net radiation flux reflects changes in the position of the snowline throughout the wet season due to the alternation of snowfall and melting periods: snow falls more frequently and lasts longer at high elevations. The spatial variability of the turbulent fluxes resulted from the air temperature lapse rate, spatially invariant relative humidity and wind speed, the computed surface temperature (and associated saturating humidity), and changes in roughness lengths (section 3.2). As the lapse rate for air temperature is steeper than for surface temperature, gains in sensible heat decrease with increasing elevation. In contrast, drier air at high elevations, due to uniform relative humidity and lower temperatures, causes more intense sublimation $(L E<0)$. Calculations resulted in a marked increase in the contribution of the turbulent fluxes (as energy losses) to the energy balance with increasing elevation. At low elevations, the gains in $H$ tended to cancel out most of the losses in $L E$ and large radiation fluxes prevailed in the energy balance. At high elevations, the energy losses in $L E$ exceeded the gains in $H$ and high snow albedo caused small net solar radiation fluxes.

[42] In the wet season, high melt rates were caused by the radiation fluxes whose spatial variations were mostly driven by albedo. The mean melt rate over the entire glacier was around $7 \mathrm{~mm}$ w.e. per day during period 1 . It decreased from around $20 \mathrm{~mm}$ w.e. per day at the snout to around $14 \mathrm{~mm}$ w.e. per day at $5150 \mathrm{~m}$ asl. In the firn area, the albedo remained high causing a small and uniformly distributed melt rate (about $5 \mathrm{~mm}$ w.e. per day). The glacier area from 4850 to $5150 \mathrm{~m}$ asl $(30 \%$ of the total surface area) produced $58 \%$ of the total meltwater. The area below $5000 \mathrm{~m}$ asl, which represents $10 \%$ of the glacier surface, produced $22 \%$ of the total meltwater. In spite of low melt rates, due to its large area, the firn area produced $42 \%$ of the total meltwater. This contribution was overestimated since the model did not adequately account for the mass and energy transfers within the snowpack. The error was small at the grid cell scale given the small energy inputs at high altitudes, but it was systematic and affected a large surface area.

\subsection{Calculations of Incoming Long-Wave Radiation}

[43] The model was run with incoming long-wave radiation derived from equations (10) and (11) and with the surface temperature adjusted to close the energy balance (section 3.1.3). The comparison with the reference run (measured $L \downarrow$ and $L \uparrow$ ) was examined during the wet season, when sky emission is highest and spatial variations in surface temperature are small; simulated $T_{s}$ ranged from -5 to $-2^{\circ} \mathrm{C}$ from the top to the snout, averaged over period 1 , whereas its mean measured value at AWS2 was $-1.4^{\circ} \mathrm{C}$. Figure 4 shows that there was no major difference in discharge whether the long-wave irradiance was simulated or measured. Differences were more apparent in late January, when net longwave radiation contributed to melt energy (Figure 6). The calculation of long-wave radiation caused a slight decrease in discharge, which may be due to (1) simulation errors on $L \downarrow$, in particular since diurnal changes in cloud cover were not simulated, and/or (2) measured $L \downarrow$ was assumed to be spatially invariant in the reference run. We found that calculating $L \downarrow$ without spatial variability did not significantly alter discharge: the largest long-wave irradiances were due to clouds which also dampened their spatial variability. This suggests that point 2 is not dominant. Sicart et al. [2010] showed that equation (10) tends to underestimate high emissions by convective clouds. Hence, (small) simulation errors in longwave irradiance reduced the meltwater discharge, slightly decreasing agreement between observed and simulated values. Nevertheless, equations (10)-(12) appear to be appropriate to simulate the variations in time and space of downward longwave radiation in distributed melt models applied to tropical glaciers.

\section{Discussion}

\subsection{Simulation Uncertainties and Validation Problems}

\subsubsection{Turbulent Fluxes}

[44] Turbulent fluxes are quite well known in the ablation area of Zongo Glacier, with an uncertainty of about $\pm 20 \%$, owing to the comparison of different methods of measurement, for example, the bulk aerodynamic method, sublimation measurement with lysimeters, and eddy covariance measurements [Wagnon et al., 1999; Ben Tahar, 2008]. The model does not account for an increase in heat advection toward the edge of the glacier, which should increase the melt rate locally but only has a minor impact on the total ablation of the glacier. Modeling assumptions resulted in an altitudinal decrease in the energy gains in the turbulent sensible heat flux due to colder air, whereas drier air caused more intense sublimation at high elevations (section 4.3). These trends are in agreement with the rare observations available on summits 
Table 2a. Monthly Mean Energy Fluxes Averaged Over the Glacier Surface in December, January, and July During the 1999-2000 Hydrological Year

\begin{tabular}{lcccccc}
\hline Period & $S\left(\mathrm{~W} \mathrm{~m}^{-2}\right)$ & $L\left(\mathrm{~W} \mathrm{~m}^{-2}\right)$ & $H\left(\mathrm{~W} \mathrm{~m}^{-2}\right)$ & $L E\left(\mathrm{~W} \mathrm{~m}^{-2}\right)$ & $R\left(\mathrm{~W} \mathrm{~m}^{-2}\right)$ & $H+L E\left(\mathrm{~W} \mathrm{~m}^{-2}\right)$ \\
\hline December & 52 & -32 & 2 & -11 & 19 & -9 \\
January & 26 & -6 & -2 & -5 & 19 & -7 \\
July & 31 & -82 & 5 & -25 & -51 & -21 \\
\hline
\end{tabular}

of tropical mountains [e.g., Wagnon et al., 2003], but their quantification is inaccurate and they do not account for wind variations, which mainly control turbulent fluxes. The energy loss in turbulent fluxes is thus an important component of the energy balance in the firn area, affecting the discharge mainly through the meltwater base flow (Figure 8). High roughness lengths tended to increase the turbulent fluxes in the simulations, whereas the assumption of spatially constant stability functions derived at low altitudes (with higher air temperatures) tended to reduce these fluxes at high altitudes. Overall, the assumption that all meltwater runoff reaches the basin outlet led to overestimation of the influence of the firn area, and hence that of the turbulent fluxes (and their uncertainties), on meltwater discharge.

[45] Turbulent fluxes affect, and depend on, surface temperature. Two options were tested: $T_{s}$ was overestimated at high elevations when it was derived from the long-wave radiation measurement in the ablation area, but was underestimated when adjusted to cancel the negative energy budgets because the subsurface heat flux was not accounted for. The second error is dominant because of large subsurface heat fluxes during cold periods. Although the method of calculating surface temperature significantly affected the turbulent fluxes, it had little effect on meltwater discharge. This is because changes in turbulent fluxes, due to $T_{s}$ whether simulated or derived from measurements, mostly occur in nomelting conditions, whereas the model derives the melt rate from the positive sums of energy fluxes.

\subsubsection{Energy Balance Closure and Model Structure}

[46] In the wet season, the radiation fluxes largely prevail in the surface energy balance and most of the glacier is continuously in melting conditions, which enables a reliable closure of the energy budget and correct simulation of the meltwater discharge. However, the model tended to overestimate the snow albedo, owing to errors in its parameterization and/or on the hourly snowfall input, which is difficult to measure accurately. Through feedback processes, small errors in snow albedo caused significant errors in meltwater discharge, especially in the wet season when the ice was sporadically covered by snow. As the parameters of albedo calculation are difficult to estimate independently from complete modeling of all energy and mass fluxes, their calibrated values may compensate for other modeling errors, thereby losing their physical interpretation. Errors in snow albedo that caused overestimation of the snow depth and underestimation of the melt rate were partly compensated by overestimation of the meltwater originating from the firn area due to poor simulation of the mass and energy transfers within the snowpack.

[47] Additional sources of uncertainties arise in the dry season because the glacier is not in permanent melting conditions; marked daily surface temperature cycles imply large subsurface heat fluxes, which were not correctly simulated. Omission of the subsurface heat flux caused the melt rate to be overly sensitive to albedo, as shown by the erroneous peaks of meltwater discharge in July (Figure 8). The turbulent fluxes associated with large uncertainties were greater than in the wet season. The sum of atmospheric energy fluxes was low, with a large relative error; even its sign, sink or source, could be erroneous. The comprehensive analysis of the uncertainties in this distributed model, which includes numerous parameters, is a complex problem beyond the scope of this paper. It would require complete exploration of the parameter space and resulting nonlinear effects caused by combined uncertainties in multiple parameters [e.g., Machguth et al., 2008].

[48] More complete models could be used; for instance, to simulate the mass and energy transfers within the snow or changes in subglacial water storage and flows. However, adding complexity to the model without additional observations would not improve the understanding of the physical processes [e.g., Klemes, 1983]. A reliable estimation of the subsurface heat fluxes would require temperature profile measurements within the first decimeters of ice or snow, which is a difficult task over long periods owing to changes in surface height. More observations in the firn area would also be required, such as temperature, water content, and density profiles in the snow, tracing experiments to document water movements, or melt rate measurements. Difficult access due to high altitudes partly explains the scarcity of observations in the accumulation area of tropical Andean glaciers.

\subsection{Seasonal Changes in Energy Fluxes and Melt Rate 5.2.1. Energy Sources of Melting}

[49] Table 2a shows the partitioning of the energy fluxes averaged over the glacier surface at three periods of the year: during the progressive establishment of the wet season (December), in the core wet season (January), and in the dry season (July). Table $2 \mathrm{~b}$ quantifies the share of each energy flux in the sum of all fluxes expressed in absolute values to show the contribution of each flux to the total energy exchange, or energy turnover. The sum of atmospheric energy fluxes was positive in December and January, and largely negative in July. During the melt period, which lasts roughly from September to May, turbulent fluxes remained

Table 2b. Monthly Energy Fluxes Averaged Over the Glacier Surface in December, January, and July During the 1999-2000 Hydrological Year, Showing the Contribution of Each Flux to the Sum of All Fluxes in Absolute Values

\begin{tabular}{lccccc}
\hline Period & $S U M_{A B S}{ }^{\mathrm{a}}\left(\mathrm{W} \mathrm{m}^{-2}\right)$ & $S^{\mathrm{b}}(\%)$ & $L(\%)$ & $H(\%)$ & $L E(\%)$ \\
\hline December & 97 & 53 & 33 & 2 & 12 \\
January & 39 & 66 & 16 & 5 & 14 \\
July & 143 & 22 & 57 & 3 & 18 \\
\hline
\end{tabular}

${ }^{\mathrm{a}} S U M_{A B S}$ is the sum of the energy fluxes in absolute values: $|S|+|L|+$ $|H|+|L E|$.

${ }^{\mathrm{b}}$ The contribution of flux $X$ was calculated as $\mid X \mathrm{l} / S U M_{A B S}$. 


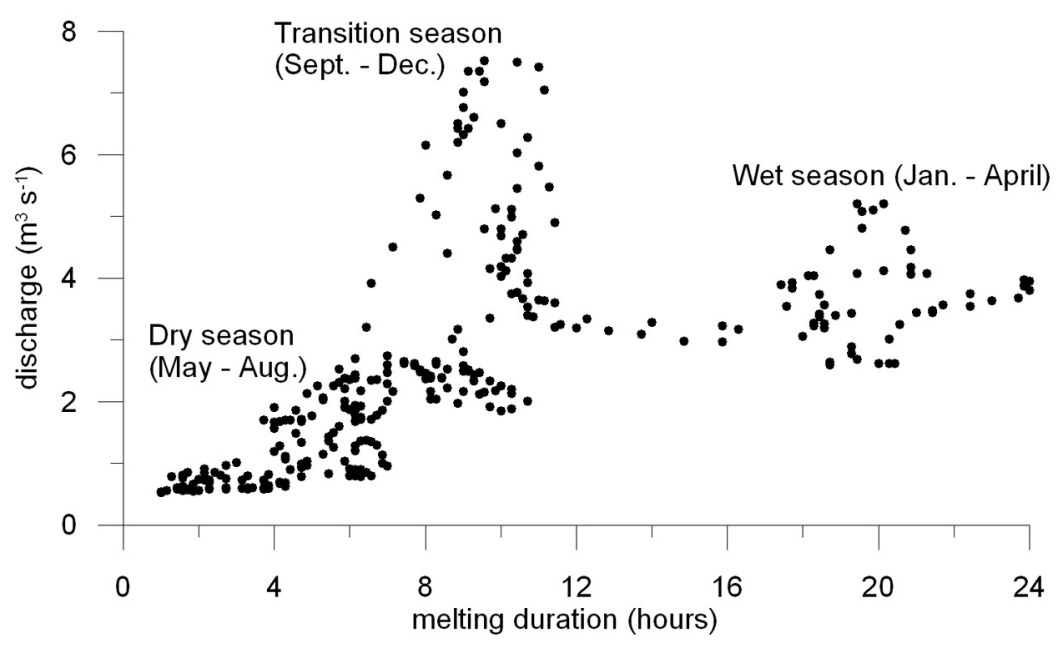

Figure 12. Daily discharge versus melt duration represented by the number of hours when $T_{s}>-1{ }^{\circ} \mathrm{C}$ at AWS2. Short melt duration corresponds to a $24 \mathrm{~h}$ period with clear skies. Running averages are over 7 days, 1999-2000.

low because of low wind speed and small temperature and humidity gradients between the glacier and the air, and radiative fluxes largely prevailed in the energy balance. From September to December, precipitation and clouds were not yet frequent and the snowline was high, causing low glacier albedo (Figure 3). Solar irradiance approached its summer peak and caused intense melting, resulting in the highest discharge of the year. A marked diurnal cycle of discharge characterized ice melting caused by solar radiation, with a short time lag before runoff from the glacier reached the basin outlet. Melt energy, mainly provided by short-wave radiation, was reduced by long-wave radiation losses due to high surface temperatures and low long-wave emissions of the atmosphere with a low cloud cover (Tables $2 a$ and $2 b$ ). Clouds and snowfall were most frequent from January to March. High long-wave emission from low warm convective clouds maintained the melt rate despite the decrease in net solar radiation due to the clouds and to the high albedo of fresh snow. The contribution of sky long-wave radiation to melt energy and the transfer of meltwater through the snow dampened the diurnal discharge cycle. In April, the end of the precipitation season caused a rise in the snowline. Lower albedo and increased sky transmissivity of solar radiation tended to counteract the decrease in potential solar radiation in winter and the reduction in long-wave incoming radiation due to the cloudless sky, so that net radiation and melt energy were not significantly reduced.

[50] Schematically, meltwater discharge was maintained thanks to the alternation of ice melting by solar radiation during clear-sky periods and snow melting by long-wave radiation during cloudy periods with frequent snowfalls. This alternation of sources of melt energy occurred at different time scales: from the September to December transition season to the January to March wet season, and in the alternation of 5-10 day periods of wet and dry conditions during the precipitation season [Garreaud, 2000; Sicart et al., 2002].

\subsubsection{Causes of Low Melt in the Dry Season}

[51] In the wet season, precipitation associated with local convection can deposit hail near the glacier front, which rapidly melts owing to low albedo. During the dry season, precipitation associated with extratropical perturbations generally deposits a thick snow cover over the entire glacier, drastically reducing the melt rate (e.g., the early June snowfall, Figure 8). The energy available for melt then remains low owing to small energy gains in solar radiation and large energy losses in long-wave radiation and in turbulent fluxes.

[52] Averaged over the entire glacier surface, the energy losses in turbulent latent heat flux were high, but lower than long-wave radiation losses (Table 2a). The turbulent latent heat flux contributed most in the dry season but never exceeded $20 \%$ of the total energy exchanges (Table $2 b$ ). At the same time, long-wave radiation losses represented around $60 \%$ of the energy exchanges. The variations in atmospheric energy fluxes were driven by radiation (Figure 9), as shown by the correlations in July: $\mathrm{r}^{2}\left(\Delta Q_{M}, R\right)=0.77$, $\mathrm{r}^{2}\left(\Delta Q_{M}, S\right)=0.36, \mathrm{r}^{2}\left(\Delta Q_{M}, L\right)=0.10, \mathrm{r}^{2}\left(\Delta Q_{M}, H+L E\right)=0.26$ $\left(\mathrm{r}^{2}\right.$ is the determination coefficient for the hourly spatially averaged fluxes during the day, $N=256$ ). Radiation fluxes dominated both energy gains (short-wave) and losses (longwave) of the glacier throughout the year. As discussed in section 5.1, large uncertainties remain concerning the turbulent fluxes but none is likely to significantly reduce the weight of these fluxes in the energy balance.

[53] The long-wave radiation deficit due to low emission from the dry, cloudless, and thin atmosphere at very high altitudes was sufficient to maintain low meltwater discharges during the dry season. The energy deficit reached maximum during daytime owing to high surface temperatures, which reduced the energy available for melting. Long-wave radiation losses caused marked cooling of the glacier during the night, which in turn, delayed the onset of melting during the day. A delay in melting can also be expected at the beginning of the wet season owing to the subsurface cold content accumulated during the dry season, as happens in spring in midlatitude glaciers.

\subsubsection{Melt Duration as an Index of Seasonal Climate} Forcing

[54] Figure 12 shows the daily discharge at the gauging station versus a point-scale index of melt duration at AWS2. The values were smoothed to account for the time lag before 
runoff from the glacier reaches the stream gauge station. During clear-sky conditions in the day, glacier melting is mostly caused by solar radiation, whereas the surface is cooled during cold nights. When the sky is overcast, the emission of long-wave radiation by clouds can maintain melting conditions throughout the night. The low discharges in the dry season were associated with a short melting period. After the September equinox, increased solar radiation and decreased surface albedo increased the energy available for melt. The meltwater discharge increased with the lengthening of the melting period, to reach a peak when clear-sky solar radiation caused intense melting for $10-12 \mathrm{~h}$ per day, around the summer solstice in December. From January on, when the wet season was fully established, frequent clouds maintained the glacier close to melting conditions day and night. Discharge was reduced but was nevertheless maintained by long-wave radiation emitted by clouds. The relationship between point-scale melt duration and total meltwater discharge thus distinguishes three seasons in the hydrological year. Figure 12 summarizes climate forcing on the glacier and shows that cloud cover and precipitation control the seasonal changes in melt energy.

[55] The annual mass balance depends on the onset of the wet season, which interrupts the period of maximal melting by solar radiation. Observations on Zongo Glacier since 1991 have shown a regular pattern of rapid increase in discharge from September to December or January, followed by a progressive decrease until the very low discharges in the dry season. The seasonality of discharge contrasts with the progressive establishment of the precipitation season and its rather sudden termination around April (Figure 2). The glacier accumulation season is short, 3-4 months in the core of the wet season, roughly from January to April [Sicart et al., 2007]. Any delay in the onset of the wet season, as happened during the 1997-1998 El Niño event, results in a very negative mass balance due to limited accumulation and very high ablation.

\section{Summary and Concluding Remarks}

[56] With the objective of investigating seasonal climate forcing on the mass balance and meltwater discharge of tropical glaciers, the spatially distributed energy balance model of Hock and Holmgren [2005] was applied to the Bolivian Zongo Glacier ( $16^{\circ} 15^{\prime} \mathrm{S}, 6000$ to $4900 \mathrm{~m}$ asl) at an hourly time step over a hydrological year. The model was adjusted to tropical high mountains mainly for the calculation of albedo, owing to the frequent alternation of melt and snowfall periods during the wet season, and of long-wave incoming radiation, owing to the pronounced seasonality of sky emission.

[57] Three seasons can be distinguished in this outer tropical glacier. In the dry season from June to August, discharge is low, mainly owing to the surface deficit in long-wave radiation due to the low emissivity of the cloudless thin atmosphere at very high altitudes, and not primarily owing to sublimation as postulated in previous studies [e.g., Kaser et al., 1996; Wagnon et al., 1999]. During the transition season from September to December, the meltwater discharge progressively increases to reach its highest annual values due to high solar irradiance, with the Sun close to zenith, and low glacier albedo. From January on, the frequent snowfalls in the wet season reduce the melt rate, which is nevertheless maintained by high long-wave radiation emitted from convective clouds. The annual mass balance depends on the onset of the wet season, which interrupts the period of high melt caused by solar radiation. Any delay in the onset of the wet season causes a very negative mass balance, owing to reduced snow accumulation and very large ablation. The mass balance is not greatly affected by turbulent fluxes, which are significant only in the dry season. These tropical Andean conditions contrast with the drier climate of highaltitude glaciers on Kilimanjaro (East Africa), where melt is limited and sublimation dominates ablation [Mölg et al., 2009b].

[58] During the wet season, radiation fluxes dominate in the surface energy balance and most of the glacier is in melting conditions, allowing for reliable closure of the energy budget and good simulation of meltwater discharge. However, the model tends to overestimate the snow albedo owing to errors in its parameterization and/or in snowfall input. The melt rate is very sensitive to albedo when thin layers of snow temporarily cover the glacier ice. Errors in albedo are partly compensated by overestimation of the meltwater runoff from the firn area due to poor simulation of the energy and mass transfers within the snowpack. The glacier is not continuously in melting conditions in the dry season; marked daily surface temperature cycles imply large subsurface heat fluxes, which are not correctly estimated.

[59] These simulations underline the need for further experimental studies. Clouds and precipitation have distinct properties in the wet and in the dry seasons, which need to be further investigated in relation with the mass balance. Observations of the melt processes and meltwater transfers are lacking in the firn area. Investigations of the atmospheric boundary layer would provide insights into wind properties (e.g., height and strength of the maximum speed of katabatic wind), which are necessary to estimate turbulent fluxes and their areal variations more accurately. Subglacial hydrology, which is related to the considerable length of the ablation period, has not yet been thoroughly investigated.

[60] Tropical glaciers are characterized by large vertical mass balance gradients of about $2 \mathrm{~m}$ w.e. $(100 \mathrm{~m})^{-1} \mathrm{yr}^{-1}$ in the ablation area [e.g., Kaser et al., 1996; Soruco et al., 2009], implying a significant contribution of the lowest areas to total ablation. The mass balance gradient is steepest in the wet season and smallest in the dry season when neither melt nor accumulation is substantial. Kuhn [1984] noted the influence of the length of the ablation period. In the present study, the simulations showed that the frequent changes in snow cover throughout the ablation season enhance the vertical mass balance gradients.

[61] The ablation and accumulation processes are closely related in tropical glaciers. Melt depends on the duration and timing of the wet season, which may have changed during the Holocene [Servant and Servant-Vildary, 2003]. Models based on annual precipitation amount (and annual temperature) may underestimate mass balance variability. In low-latitude mountains estimates of precipitation at intraannual scales are rare in past records and not very reliable in scenarios of future climate changes. Climate reconstitutions based on past glacier extents and studies of the impact of future glacier changes are therefore challenging in tropical mountains. 
[62] Acknowledgments. The glaciological program is supported by the Institut de Recherche pour le Développement (IRD). This work was sponsored by the French ORE network Glacioclim and the ANR program TAG 05-JCJC-0135. The authors are also grateful to three anonymous reviewers for their useful comments on the manuscript. We thank Patrick Wagnon, Yves Lejeune, and especially Michel Vallon for stimulating discussions.

\section{References}

Beljaars, A. C. M., and A. A. M. Holtslag (1991), Flux parameterization over land surfaces for atmospheric models, J. Appl. Meteorol., 30, 327-341, doi:10.1175/1520-0450(1991)030<0327:FPOLSF>2.0.CO;2.

Ben Tahar, V. (2008), Caractérisation de la couche limite atmosphérique sur le glacier tropical Zongo (Bolivie) et estimation des flux turbulents, Master thesis, 47 pp., Univ. du Sud Toulon-Var, La Garde, France.

Bergen, J. D. (1971), The relation of snow transparency to density and air permeability in a natural snow cover, J. Geophys. Res., 76, 7385-7388, doi:10.1029/JC076i030p07385.

Berthier, E., J. E. Sicart, P. Wagnon, R. Gallaire, J. P. Chazarin, P. Ribstein, B. Pouyaud, B. Francou, and H. Baldivieso (2001), Mesures météorologiques, hydrologiques et glaciologiques, année hydrologique 1998-99, report, 93 pp., IRD, La Paz, Bolivia.

Beven, K. J. (1989), Changing ideas in hydrology: The case of physically based models, J. Hydrol., 105, 157-172, doi:10.1016/0022-1694(89) 90101-7.

Bradley, R. S., F. T. Keimig, H. F. Diaz, and D. R. Hardy (2009), Recent changes in freezing level heights in the Tropics with implications for the deglacierization of high mountain regions, Geophys. Res. Lett., 36, L17701, doi:10.1029/2009GL037712.

Braun, M., and R. Hock (2004), Spatially distributed surface energy balance and ablation modelling on the ice cap of King George Island (Antarctica), Global Planet. Change, 42, 45-58, doi:10.1016/j.gloplacha.2003.11.010.

Brutsaert, W. (1975), On a derivable formula for long-wave radiation from clear skies, Water Resour. Res., 11, 742-744, doi:10.1029/ WR011i005p00742.

Favier, V., P. Wagnon, J. P. Chazarin, L. Maisincho, and A. Coudrain (2004), One-year measurements of surface heat budget on the ablation zone of Antizana glacier 15, Ecuadorian Andes, J. Geophys. Res., 109, D18105, doi:10.1029/2003JD004359.

Francou, B., M. Vuille, P. Wagnon, J. Mendoza, and J. E. Sicart (2003), Tropical climate change recorded by a glacier in the central Andes during the last decades of the twentieth century: Chacaltaya, Bolivia, $16^{\circ} \mathrm{S}$, J. Geophys. Res., 108(D5), 4154, doi:10.1029/2002JD002959.

Garreaud, R. D. (2000), Intraseasonal variability of moisture and rainfall over South American Altiplano, Mon. Weather Rev., 128, 3337-3346, doi:10.1175/1520-0493(2000)128<3337:IVOMAR>2.0.CO;2.

Garreaud, R. D., M. Vuille, R. Compagnucci, and J. Marengo (2009), Present-day South American climate, Palaeogeogr. Palaeoclimatol. Palaeoecol., 281(3-4), 180-195, doi:10.1016/j.palaeo.2007.10.032.

Grayson, R. B., I. D. Moore, and T. A. McMahon (1992), Physically based hydrologic modeling: 2. Is the concept realistic?, Water Resour. Res., 28 2659-2666, doi:10.1029/92WR01259.

Grenfell, T. C., and G. A. Maykut (1977), The optical properties of ice and snow in the arctic basin, J. Glaciol., 18(80), 445-463.

Greuell, W., W. Knap, and C. Smeets (1997), Elevational changes in meteorological variables along a midlatitude glacier during summer, J. Geophys. Res., 102, 25,941-25,954, doi:10.1029/97JD02083.

Halldin, S., and A. Lindroth (1992), Errors in net radiometry: Comparison and evaluation of six radiometer designs, J. Atmos. Oceanic Technol., 9, 762-783, doi:10.1175/1520-0426(1992)009<0762:EINRCA>2.0.CO;2.

Hardy, D. R., M. Vuille, C. Braun, F. Keimig, and R. S. Bradley (1998), Annual and daily meteorological cycles at high altitude on a tropical mountain, Bull. Am. Meteorol. Soc., 79(9), 1899-1913, doi:10.1175/ 1520-0477(1998)079<1899:AADMCA>2.0.CO;2.

Hastenrath, S. (1978), Heat-budget measurements on the Quelccaya Ice Cap, Peruvian Andes, J. Glaciol., 20(82), 85-97.

Hastenrath, S. (2009), Past glaciation in the tropics, Quat. Sci. Rev., 28(9-10), 790-798, doi:10.1016/j.quascirev.2008.12.004.

Hock, R., and B. Holmgren (2005), A distributed surface energy-balance model for complex topography and its application to Storglaciaren, Sweden, J. Glaciol., 51(172), 25-36, doi:10.3189/172756505781829566.

Jomelli, V., V. Favier, A. Rabatel, D. Brunstein, G. Hoffmann, and B. Francou (2009), Fluctuations of glaciers in the tropical Andes over the last millennium and palaeoclimatic implications: A review, Palaeogeogr. Palaeoclimatol. Palaeoecol., 281(3-4), 269-282, doi:10.1016/j. palaeo.2008.10.033.

Jones, P. D., T. J. Osborn, and K. R. Briffa (2001), The evolution of climate over the last millennium, Science, 292, 662-667, doi:10.1126/science. 1059126.
Kaser, G. (1999), A review of the modern fluctuations of tropical glaciers, Global Planet. Change, 22, 93-103, doi:10.1016/S0921-8181(99)00028-4. Kaser, G., S. Hastenrath, and A. Ames (1996), Mass balance profiles on tropical glaciers, Z. Gletscherkd. Glazialgeol., 32, 75-81.

Klemes, V. (1983), Conceptualization and scale in hydrology, J. Hydrol., 65, 1-23, doi:10.1016/0022-1694(83)90208-1.

Kuhn, M. (1984), Mass budget imbalances as criterion for climatic classification of glaciers, Geogr. Ann., 66(3), 229-238, doi:10.2307/520696.

Kuhn, M., E. Dreiseitl, S. Hofinger, G. Mark1, N. Span, and G. Kaser (1999), Measurements and models of the mass balance of Hintereisferner, Geograf. Ann., 81, 659-670.

Lejeune, Y., P. Wagnon, L. Bouilloud, P. Chevallier, P. Etchevers, E. Martin, J. E. Sicart, and F. Habets (2007), Melting of snow cover in a tropical mountain environment in Bolivia: Processes and modeling, J. Hydrometeorol., 8(4), 922-937, doi:10.1175/JHM590.1.

Machguth, H., R. S. Purves, J. Oerlemans, M. Hoelzle, and F. Paul (2008), Exploring uncertainty in glacier mass balance modelling with Monte Carlo simulation, Cryosphere, 2(2), 191-204, doi:10.5194/tc-2-1912008

Mölg, T., N. J. Cullen, and G. Kaser (2009a), Solar radiation, cloudiness and longwave radiation over low-latitude glaciers: Implications for mass-balance modelling, J. Glaciol., 55(190), 292-302, doi:10.3189/ 002214309788608822 .

Mölg, T., N. J. Cullen, D. R. Hardy, M. Winkler, and G. Kaser (2009b), Quantifying climate change in the tropical midtroposphere over East Africa from glacier shrinkage on Kilimanjaro, J. Clim., 22(15), 4162-4181, doi:10.1175/2009JCLI2954.1.

Oerlemans, J., and W. Knap (1998), A 1 year record of global radiation and albedo in the ablation zone of Morteratschgletscher, Switzerland, J. Glaciol., 44(147), 231-238.

Platt, C. M. (1966), Some observations of the climate of Lewis Glacier, Mount Kenya, during the rainy season, J. Glaciol., 6(44), 267-287.

Plüss, C., and A. Ohmura (1997), Longwave radiation on snow-covered mountainous surfaces, J. Appl. Meteorol., 36, 818-824, doi:10.1175/ 1520-0450-36.6.818.

Ribstein, P., E. Tiriau, B. Francou, and R. Saravia (1995), Tropical climate and glacier hydrology: A case study in Bolivia, J. Hydrol., 165, 221-234 doi:10.1016/0022-1694(94)02572-S.

Seibert, J. (1999), Conceptual Runoff Models: Fiction or Representation of Reality?, 52 pp., Uppsala Univ. Press, Uppsala, Sweden.

Servant, M., and S. Servant-Vildary (2003), Holocene precipitation and atmospheric changes inferred from river paleowetlands in the Bolivian Andes, Palaeogeogr. Palaeoclimatol. Palaeoecol., 194(1-3), 187-206, doi:10.1016/S0031-0182(03)00277-3.

Sicart, J. E., P. Ribstein, P. Wagnon, and D. Brunstein (2001), Clear sky albedo measurements on a sloping glacier surface: A case study in the Bolivian Andes, J. Geophys. Res., 106, 31,729-31,737, doi:10.1029/ 2000JD000153.

Sicart, J. E., P. Ribstein, J. P. Chazarin, and E. Berthier (2002), Solid precipitation on a tropical glacier in Bolivia measured with an ultrasonic depth gauge, Water Resour. Res., 38(10), 1189, doi:10.1029/2002WR001402.

Sicart, J. E., P. Wagnon, and P. Ribstein (2005), Atmospheric controls of the heat balance of Zongo Glacier $\left(16^{\circ} \mathrm{S}\right.$, Bolivia), J. Geophys. Res., 110, D12106, doi:10.1029/2004JD005732.

Sicart, J. E., J. W. Pomeroy, R. L. H. Essery, and D. Bewley (2006), Incoming long-wave radiation to melting snow: Observations, sensitivity and estimation in northern environments, Hydrol. Processes, 20(17), 3697-3708, doi:10.1002/hyp.6383.

Sicart, J. E., P. Ribstein, B. Francou, B. Pouyaud, and T. Condom (2007), Glacier mass balance of tropical Zongo Glacier, Bolivia, comparing hydrological and glaciological methods, Global Planet. Change, 59, 27-36, doi:10.1016/j.gloplacha.2006.11.024.

Sicart, J. E., R. Hock, P. Ribstein, and J. P. Chazarin (2010), Sky long-wave radiation on tropical Andean glaciers: Parameterization and sensitivity to atmospheric variables, J. Glaciol., 56(199), 854-860, doi:10.3189/ 002214310794457182 .

Smeets, C., and M. R. van den Broeke (2008), Temporal and spatial variations of the aerodynamic roughness length in the ablation zone of the Greenland ice sheet, Boundary Layer Meteorol., 128(3), 315-338, doi:10.1007/s10546-008-9291-0.

Soruco, A., C. Vincent, B. Francou, and J. F. Gonzalez (2009), Glacier decline between 1963 and 2006 in the Cordillera Real, Bolivia, Geophys. Res. Lett., 36, L03502, doi:10.1029/2008GL036238.

Troll, C. (1941), Studien zur vergleichenden Geographie der Hochgebirge der Erde, Bonner Mitt. 21, Univ. Bonn, Bonn, Germany.

U.S. Army Corps of Engineers (1956), Summary report of the snow investigations, snow hydrology, report, 437 pp., N. Pac. Div., Portland, Oreg.

Vera, C., et al. (2006), Toward a unified view of the American Monsoon Systems, J. Clim., 19(20), 4977-5000, doi:10.1175/JCLI3896.1. 
Wagnon, P., P. Ribstein, B. Francou, and B. Pouyaud (1999), Annual cycle of energy balance of Zongo Glacier, Cordillera Real, Bolivia, J. Geophys. Res., 104, 3907-3923, doi:10.1029/1998JD200011.

Wagnon, P., P. Ribstein, B. Francou, and J. E. Sicart (2001), Anomalous heat and mass budget of Glaciar Zongo, Bolivia, during the 1997/98 El Nino year, J. Glaciol., 47(156), 21-28, doi:10.3189/ 172756501781832593.

Wagnon, P., J. E. Sicart, E. Berthier, and J. P. Chazarin (2003), Wintertime high-altitude surface energy balance of a Bolivian glacier, Illimani, $6340 \mathrm{~m}$ above sea level, J. Geophys. Res., 108(D6), 4177, doi:10.1029/ 2002JD002088.

Warren, S. G. (1982), Optical properties of snow, Rev. Geophys., 20(1), 67-89, doi:10.1029/RG020i001p00067.
Warren, S. G. (1984), Impurities in snow: Effects on albedo and snowmelt, Ann. Glaciol., 5, 177-179.

R. Hock, Geophysical Institute, University of Alaska Fairbanks, Fairbanks, AK 99775, USA.

M. Litt and E. Ramirez, IHH, UMSA, La Paz 00095, Bolivia.

P. Ribstein, UMR Sisyphe, Université Pierre et Marie Curie, F-75252 Paris CEDEX 05, France.

J. E. Sicart, LTHE, Bâtiment CERMO, Domaine Universitaire, BP 53, F-38041 Grenoble CEDEX 09, France. (jean-emmanuel.sicart@ird.fr) 